\title{
Aging-Shifted Prostaglandin Profile in Endothelium as a Factor in Cardiovascular Disorders
}

\author{
Hao Qian, Na Luo, and Yuling Chi \\ Department of Medicine, Albert Einstein College of Medicine, Bronx, NY 10461, USA \\ Correspondence should be addressed to Yuling Chi, yuling.chi@einstein.yu.edu
}

Received 28 March 2011; Revised 10 October 2011; Accepted 28 October 2011

Academic Editor: Paula Bickford

Copyright () 2012 Hao Qian et al. This is an open access article distributed under the Creative Commons Attribution License, which permits unrestricted use, distribution, and reproduction in any medium, provided the original work is properly cited.

\begin{abstract}
Age-associated endothelium dysfunction is a major risk factor for the development of cardiovascular diseases. Endotheliumsynthesized prostaglandins and thromboxane are local hormones, which mediate vasodilation and vasoconstriction and critically maintain vascular homeostasis. Accumulating evidence indicates that the age-related changes in endothelial eicosanoids contribute to decline in endothelium function and are associated with pathological dysfunction. In this review we summarize currently available information on aging-shifted prostaglandin profiles in endothelium and how these shifts are associated with cardiovascular disorders, providing one molecular mechanism of age-associated endothelium dysfunction and cardiovascular diseases.
\end{abstract}

\section{Introduction}

Cardiovascular disorders, including atherosclerosis, coronary artery disease, heart failure, and hypertension, remain the leading cause of death worldwide [1]. These diseases are among several pathological conditions that are associated with aging [2-4], and age is a primary risk factor for their development $[5,6]$. Endothelium is a thin layer of epithelial cells which line the interior of lymph and blood vessels and is a major component of the vascular wall. One important contributor to the development of cardiovascular diseases is a dysfunctional endothelium. Endothelial dysfunction is considered a fair predictor of cardiovascular diseases $[4,7-11]$.

Furchgott and Zawadzki unequivocally demonstrated that the endothelium is required for normal vessel relaxation [12]. Besides inducing relaxation, normal and healthy endothelium regulates vessel wall permeability, blood flow, vascular tone, and structure and exerts anticoagulant and fibrinolytic properties [13]. Aging adversely affects these normal functions of the endothelium, enhancing vasospasm and thrombosis, leading to eventual cardiovascular diseases [4, 14-16]. Age-impaired vascular relaxation has been shown in different human vascular beds including brachial artery, aorta, coronary artery, carotid, and mesenteric microvessels [14-21]. In line with these reports, additional evidence has been obtained in different vascular beds of animals including dogs $[2,22]$, rats $[2,23-32]$, and mice $[33,34]$. This reduced relaxation is accompanied with increased blood pressure [35-39]. Elevated blood pressure is an important cardiovascular risk factor that can eventually lead to heart failure.

Normal endothelial function is regulated by a controlled balance between endothelium-dependent relaxing factors and endothelium-dependent contracting factors. The main vasoactive factors released by endothelial cells are nitric oxide (NO) and cyclooxygenase- (COX-) derived eicosanoids [4, $40,41]$. NO production has been shown to be reduced with aging [42-45]. There is less information on how eicosanoids change in the endothelium with age. It is also not well understood how changes in eicosanoid profile might contribute to endothelium dysfunction. Nevertheless, accumulating evidence indicates that the age-related changes in endothelial eicosanoids contribute to endothelium dysfunction and to the development of age-associated cardiovascular diseases.

In endothelium, there are six primary cyclooxygenase(COX-) derived eicosanoids, prostaglandin $\mathrm{H}_{2}\left(\mathrm{PGH}_{2}\right)$, prostaglandin $\mathrm{I}_{2}\left(\mathrm{PGI}_{2}\right.$, prostacyclin), prostaglandin $\mathrm{E}_{2}$ $\left(\mathrm{PGE}_{2}\right)$, prostaglandin $\mathrm{F}_{2 \alpha}\left(\mathrm{PGF}_{2 \alpha}\right)$, prostaglandin $\mathrm{D}_{2}$ $\left(\mathrm{PGD}_{2}\right)$, and thromboxane $\mathrm{A}_{2}\left(\mathrm{TxA}_{2}\right)$ (Figure 1). These eicosanoids are local hormones that are synthesized by virtually all mammalian tissues [46] and act at or near their 


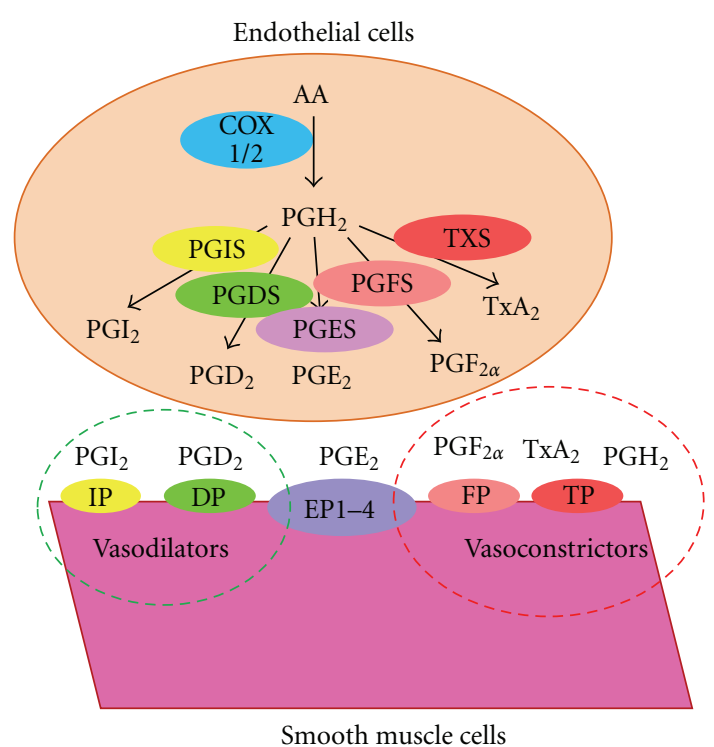

FIgure 1: Synthesis and signaling of PGs in the vascular system. Upon stimulation, AA is released from the endothelial cell membrane to the cytosol where it is enzymatically converted to $\mathrm{PGH}_{2}$ by COX1 and COX2. Subsequently, $\mathrm{PGH}_{2}$ is transformed to $\mathrm{PGI}_{2}, \mathrm{PGE}_{2}, \mathrm{PGD}_{2}, \mathrm{PGF}_{2 \alpha}$, and $\mathrm{TxA}_{2}$. These substances, as well as untransformed $\mathrm{PGH}_{2}$, are released out of endothelial cells and into the circulation, where they interact with their receptors localized on the smooth muscle cell surface and trigger vasoactive signals.

sites of synthesis in both autocrine and paracrine fashion. They trigger a vast array of biological signals, among which are vasodilation, vasoconstriction, and platelet aggregation [47-49]. In fact, the eicosanoids were the first identified endothelium-derived vasoactive factors [50, 51]. Although there is conflicting evidence [52-54], the majority of the literature shows that $\mathrm{PGI}_{2}$ and $\mathrm{PGD}_{2}$ are vasodilators [55-59], whereas $\mathrm{PGH}_{2}, \mathrm{PGF}_{2 \alpha}$, and $\mathrm{TxA}_{2}$ are vasoconstrictors and/or platelet aggregation inducers $[53,54,60-66]$. $\mathrm{PGE}_{2}$ can induce vasodilation $[47,67-70]$ or vasoconstriction $[53,54$, 71-73], depending on the vascular bed and concentration $[74,75]$. In healthy endothelium, these vasodilators and vasoconstrictors, coexisting with other vasoactive factors, are held in balance to maintain normal vascular functions. The aging process shifts this balanced profile toward a proconstrictive mediator profile $[76,77]$. In this paper, we summarize and discuss how endothelium-derived eicosanoid profile changes with age and how those changes might contribute to age-associated endothelium dysfunction.

There is limited data on how eicosanoids change in humans [4], and most experiments have been conducted in animal models and most commonly in rat [2]. Rats of 1.5-2 months or less are considered immature, rats of 3-6 months are considered young adult, and rats of approximately 24 months or more are considered aged, though there are differences between strains [2].

\section{Cyclooxygenases and $\mathrm{PGH}_{2}$}

There are two isoforms of the cyclooxygenases (COX1 and COX2) encoded by two different genes. Both COX1 and
COX2 are expressed in the endothelial and vascular smooth muscle cells, and the expression levels are 20-fold higher in endothelial cells than in smooth muscle cells [78]. In endothelium, both of the COX enzymes are constitutively expressed $[79,80]$. However, they are also inducible, for instance, by shear stress [79-81]. Endothelial cells express COX1 preferentially over COX2 [82, 83].

In human mesenteric microvessels of individuals greater than 80 years of age, COX1 levels are 50\% increased, while COX2 levels are slightly decreased [21]. In normotensive rats, both COX1 and COX2, in either whole vascular tissue or endothelial cells from vasculatures, are increased with aging from 1-fold to 5-fold [29, 42, 63, 84-86]. Comparable effects of aging on COX1 and COX2 expression levels have been observed in mice $[33,34]$. At similar ages, COX1 or COX2 expression, measured at the mRNA or protein levels, is almost doubled in the aorta of spontaneous hypertensive rats (SHRs) as compared to normotensive control Wistar-Kyoto (WKY) rats $[63,84,87,88]$. Similar increases in COX1 and COX2 were observed in $\mathrm{N}^{\omega}$-nitro-L-arginine methyl ester(L-NAME-) induced hypertensive rats as compared to control Sprague-Dawley rats [89]. Increased COX2 was also reported in the renal artery of hypertensive patients [89]. These data indicate that there are age-associated increases in COX1 and COX2 levels, as well as an association between elevated COX1/COX2 levels, in both animal models and human studies, and clinical cardiovascular disorders.

Upon stimulation, arachidonic acid (AA) is released from the cell membrane to the cytosol where it is enzymatically converted to $\mathrm{PGH}_{2}$ by COX1 and COX2 (also referred to as synthase, PGHS1, and synthase 2, PGHS2, resp.). As shown in Figure 1, $\mathrm{PGH}_{2}$ is the common precursor of other prostaglandins and $\mathrm{TxA}_{2}$. It is transformed to various PGs and $\mathrm{TxA}_{2}$ by a corresponding specific terminal synthase. Besides serving as a common precursor, untransformed $\mathrm{PGH}_{2}$ can trigger signals such as vasoconstriction and platelet aggregation by interacting with $\mathrm{TxA}_{2}$ receptor (TP) [25, 26, 90-99]. Although no evidence has directly shown the attenuation of untransformed and bioactive $\mathrm{PGH}_{2}$ during aging or in cardiovascular pathology, likely due to instability and difficulty in measurement $[25,26,91,92,95,96]$, increased COX1 and COX2 associated with aging $[21,29,42,63,84-$ $86]$ and hypertension $[63,84,87,88]$ would be predicted to result in increases in untransformed $\mathrm{PGH}_{2}$. Indirect evidence is provided by reports of reduced vasoconstriction of aortas of aged and/or hypertensive rats by inhibitors of $\mathrm{PGH}_{2}$ synthases, rather than $\mathrm{TxA}_{2}$ synthase (TXS) [25, 26, 91, 92, 96]. Although the vascular contraction induced by AA has mainly been attributed to $\mathrm{TxA}_{2}[100,101]$, the efficacy of PGHS inhibition, but poor efficacy for a TXS inhibitor, in inducing relief from vasoconstriction provides evidence for $\mathrm{PGH}_{2}$ as a vasoconstrictor $[91,92,96]$.

\section{3. $\mathbf{P G I}_{2}$}

$\mathrm{PGI}_{2}$ (prostacyclin) is the first described metabolite of arachidonic acid, and endothelium is the major site of its biosynthesis $[51,57]$. In endothelium, both COX1 and 
COX2 are the upstream contributors of $\mathrm{PGI}_{2}$ synthesis $[80$, 102-104]. $\mathrm{PGI}_{2}$ is synthesized by its terminal specific $\mathrm{PGI}_{2}$ synthase (PGIS) [105, Figure 1]. PGIS colocalizes with COX1 in endothelial cells [106]. In endothelium, PGIS is by far the most abundant PG terminal synthase, with its expression level 5-100-fold higher than the other PG terminal synthases $[54,64,65,84]$. Accordingly, $\mathrm{PGI}_{2}$ is the most abundant endothelial eicosanoid, with expression levels 10-100-fold higher than that of the other eicosanoids in humans [107, $108]$ and in animals $[54,97,109,110]$.

$\mathrm{PGI}_{2}$ triggers potent vasodilation $[51,57]$ by interacting with the $\mathrm{PGI}_{2}$ receptor (IP) (Figure 1), which located in smooth muscle cells $[108,111]$. The vasodilation effect of $\mathrm{PGI}_{2}$ has also been shown in pig coronary arteries at low concentrations [58]. At higher concentrations $\mathrm{PGI}_{2}$ may induce vasoconstriction $[32,54,64] . \mathrm{PGI}_{2}$ cannot cause vasoconstriction until its concentration reached $1 \mu \mathrm{M}$ or higher. $1 \mu \mathrm{M}$ is 1000 -fold higher than the endogenous concentration of $\mathrm{PGI}_{2}$, which is in the $0.2-1 \mathrm{nM}$ range [112]. Even at elevated concentrations, $\mathrm{PGI}_{2}$ is a weak vasoconstrictor and induces modest tension in the rat aorta $[32,54,64]$. Modest vasoconstrictive effects of $\mathrm{PGI}_{2}$ may emanate from weak cross-activation of TP, which can induce vasoconstriction [49]. At lower concentrations, $\mathrm{PGI}_{2}$, especially endogenous $\mathrm{PGI}_{2}$, is a vasodilator. In addition, $\mathrm{PGI}_{2}$ is the most potent endogenous anticoagulation agent [113]. The vasodilation and anticoagulation effects of $\mathrm{PGI}_{2}$ have been confirmed by a recent report showing that IP deletion in mice results in hypertension and reduced anticoagulation activity [114].

In human blood, $\mathrm{PGI}_{2}$, measured as $\mathrm{PGF}_{1 \alpha}$, is $400 \mathrm{pg} / \mathrm{mL}$ in new born infants, $230 \mathrm{pg} / \mathrm{mL}$ in infants, $150 \mathrm{pg} / \mathrm{mL}$ in adolescents, and $85 \mathrm{pg} / \mathrm{mL}$ in adults [112]. Age-associated $\mathrm{PGI}_{2}$ decline is also observed in urine of humans $[115,116]$. The endothelium is the main site for $\mathrm{PGI}_{2}$ synthesis $[50,51]$. Although there has been no report on $\mathrm{PGI}_{2}$ production in isolated human vessels, $\mathrm{PGI}_{2}$ levels were reported to decline in cultured human vascular endothelial cells during serial passage [117-119]. Based on these reports, one would expect that PGIS in endothelium decreases with age. Yet there have been no reports evaluating age-associated PGIS changes in the human endothelium. In the endothelial cells from rat aorta, there is a slight and insignificant age-associated decrease in PGIS mRNA [84]. However, additional evidence shows that mRNA or protein of PGIS is $2-4$-fold higher in aorta or coronary arteries of aged normotensive rats $[85,86,110,120]$ suggesting that lower PGI levels may be caused by increased $\mathrm{PGI}_{2}$ degradationwith age, rather than the change in $\mathrm{PGI}_{2}$ synthesis. In fact, there is no apparent correlation between circulating $\mathrm{PGI}_{2}$ level with level of endothelial PGIS, suggesting the necessity of investigation of the effects of age on the metabolism/degradation of $\mathrm{PGI}_{2}$. More work is needed to determine whether circulating $\mathrm{PGI}_{2}$ correlates to endothelial $\mathrm{PGI}_{2}$ and to clarify the effects of age on $\mathrm{PGI}_{2}$ in the endothelium and in the circulation. Age-associated reduction in IP level has been consistently reported in rats $[84,85]$. The reduced IP is expected to lead to reduced sensitivity to $\mathrm{PGI}_{2}$ effects. Consistently, dilation in response to $\mathrm{PGI}_{2}$ is significantly blunted in aged humans as determined by forearm blood flow measurements [121].

Reports on the change in $\mathrm{PGI}_{2}$ or PGIS under pathological conditions, such as hypertension, are contradictory. While one group reported a $50 \%$ reduction in $\mathrm{PGI}_{2}$ in SHR aorta as compared to WKY aorta [96], another group reported insignificant differences in PGI $_{2}$ levels in SHR and WYK rats $[64,65]$. In addition, Tang and Vanhoutte reported that $\mathrm{PGI}_{2}$ mRNA is 4 -fold higher in the endothelial cells of SHR aorta than in WKY aorta [84]. These limited and inconsistent reports indicate a need for more complete and thorough investigations into how aging affects $\mathrm{PGI}_{2}$, its synthase, receptor, and metabolism. Moreover, clarifying $\mathrm{PGI}_{2}$ effects in the development of cardiovascular disorders in animal models and in humans could be of potential therapeutic significance.

\section{4. $\mathrm{PGE}_{2}$}

Prostaglandin $\mathrm{E}_{2}\left(\mathrm{PGE}_{2}\right)$ is the most abundant prostaglandin in the human body. In endothelium, however, its level is lower than that of $\mathrm{PGI}_{2}$, in line with a lower expression level of the corresponding synthases, which are 5-100-fold lower than PGIS [54, 64, 65, 84]. There are three types of known $\mathrm{PGE}_{2}$ synthases (PGESs), the cytosolic PGES (cPGES) and two forms of membrane PGES, mPGES1 and mPGES2 [122, Figure 1]. cPGES is constitutively expressed and functionally coupled to COX1 $[122,123]$. mPGES1 is inducible and functionally coupled with COX2 [124] and is the major $\mathrm{PGE}_{2}$ synthase responsible for $\mathrm{PGE}_{2}$ production [123]. In endothelium, the expression levels of the PGESs are comparable to other PG synthases $[54,64,65,84]$. Consistently, the amount of $\mathrm{PGE}_{2}$ in endothelium is comparable to other PGs, but lower than the amount of $\mathrm{PGI}_{2}[54,97,107-$ $110,125]$. In further accord, the contribution of $\mathrm{PGE}_{2}$ to endothelium-dependent vasoaction is marginal [84, 125]. Chen et al. showed that deletion of mPGES1 in mice resulted in abolished production of $\mathrm{PGE}_{2}$ but did not affect blood pressure [114]. Yang, on the other hand, showed that mPGES1 deletion in mice resulted in exaggerated hypertensive in response to high salt and angiotensin II infusion [126], suggesting that mPGES1 may be an important physiological regulator of blood pressure. While the role of MPGES1 in blood pressure regulation is debatable, mPGES1 is implicated in atherosclerosis. Deletion of mPGES1 in mice retards atherosclerosis development [127].

$\mathrm{PGE}_{2}$ acts through four $\mathrm{PGE}_{2}$ receptors (EP1, EP2, EP3, and EP4), which are mainly located in the smooth muscle cells in the vessels $[125,128$, Figure 1]. Activation of EP1 and EP3 receptors induces calcium mobilization/release and inhibits adenylyl cyclase release, which triggers vasoconstrictions [111, 129]. In contrast, activation of EP2 and EP4 receptors stimulates adenylyl cyclase and induces cyclic adenosine monophosphate release, which triggers vasorelaxation $[111,129]$. The vascular actions of $\mathrm{PGE}_{2}$ are complex due to the opposing vasoactions triggered by the binding of $\mathrm{PGE}_{2}$ to the variant $\mathrm{PGE}_{2}$ receptors. Depending on the circumstances, $\mathrm{PGE}_{2}$ may be vasodilating $[47,67-70]$ or vasoconstricting $[53,54,71-73]$. In addition to the distributions 
of different $\mathrm{PGE}_{2}$ receptors expressed in the vascular system, $\mathrm{PGE}_{2}$ concentration is also important. This complexity likely explains the reported inconsistent effects of mPGES1 deletion on blood pressure $[114,126]$. $\mathrm{PGE}_{2}$ has a biphasic effect on human blood platelet aggregation. At low concentrations (0.01-1 $\mu \mathrm{M})$, it potentiates platelet aggregation, and, at higher concentrations $(10 \mu \mathrm{M})$, it inhibits ADP- and collagen-induced aggregation in platelet rich plasma [71, 130-132]. The endogenous $\mathrm{PGE}_{2}$ concentration is below $1 \mu \mathrm{M}$ [133], making $\mathrm{PGE}_{2}$ a stimulator of atherosclerosis. Thus, reduced $\mathrm{PGE}_{2}$ level by mPGES1 deletion retards atherosclerosis development [127].

There is little information available on age-related changes in any of the PGESs, $\mathrm{PGE}_{2}$, or EPs. A recent report by Tang and Vanhoutte revealed that while cPGES and mPGES1 in the aorta endothelial cells are insignificantly higher in aged rats, mRNA of mPGES2 is 5-fold higher [84], which can presumably result in higher level of $\mathrm{PGE}_{2}$. $\mathrm{PGE}_{2}$ secreted from coronary arteries is increased in aged rat as compared to young rats [120]. Expression of EP1-4 increased with age, with EP4 elevated 2-fold in endothelial cells from rats of 72 weeks as compared with rats of 36 weeks [84]. Since vasoaction depends on the ligand and the type of receptors, ageincreased $\mathrm{PGE}_{2}$ and $\mathrm{EP} 4$ are assumed to predispose to increased vasodilation. Further investigation is required to determine the effect of age-related changes in $\mathrm{PGE}_{2}$ and its synthases and receptors in different vascular beds and on relaxation/constriction of vasculatures.

\section{5. $\mathbf{P G F}_{2 \alpha}$}

There are two isomers of prostaglandin $\mathrm{F}_{2 \alpha}$. One is $\mathrm{PGF}_{2 \alpha}$, and the other is $9 \alpha, 11 \beta-\mathrm{PGF}_{2}$ [134-137]. They are transformed from $\mathrm{PGH}_{2}$ by the membrane-associated 9,11-endoperoxide reductase and from $\mathrm{PGD}_{2} / \mathrm{PGE}_{2}$ by cytosolic $\mathrm{PGD}_{2}$ 11-ketoreductase/ $\mathrm{PGE}_{2}$ 9-ketoreductase, respectively [138, Figure 1]. In endothelium, the level of $\mathrm{PGF}_{2 \alpha}$ is similar to that of $\mathrm{PGE}_{2}$, but much lower than that of $\mathrm{PGI}_{2}[54,97,107-$ $110,125]$, corresponding to low abundance of $\mathrm{PGF}_{2 \alpha}$ cognate synthase (PGFS) in the endothelium $[54,64,65,84]$.

$\mathrm{PGF}_{2 \alpha}$ has its own specific receptor (FP), which is expressed in endothelium and in vascular smooth muscle cells [139-143, Figure 1]. $\mathrm{PGF}_{2 \alpha}$ can also interact with TP [54]. Interaction between $\mathrm{PGF}_{2 \alpha}$ and its receptor generates calcium release and triggers potent vasoconstriction [144-148]. Deletion of FP reduces arterial blood pressure and delays atherogenesis in hyperlipidemic mice [149]. $\mathrm{PGF}_{2 \alpha}$ has also been indicated in promoting cardiac hypertrophy [150-152]. Although $\mathrm{PGF}_{2 \alpha}$ is a potent vasoconstrictor, the contribution of $\mathrm{PGF}_{2 \alpha}$ to endothelium-dependent contractions is minimal in most cases due to its relatively low abundance in the endothelium [54, 97, 107-110, 125].

Information on the effects of aging on $\mathrm{PGF}_{2 \alpha}$ is limited. PGFS mRNA was doubled in the endothelial cells from aged rat aorta as compared to that from young rat aorta [84]. Consistently, $\mathrm{PGF}_{2 \alpha}$ is 2-fold higher in the aorta of aged rats versus young rats $[110,148]$. Change in FP mRNA in the endothelial cells of rat aorta with age, however, is insignificant [84]. Basal $\mathrm{PGF}_{2 \alpha}$ is slightly higher in the aorta of
SHRs than that of WKY rats, but the difference is increased upon acetylcholine stimulation [54]. Research needs to be conducted to obtain more complete information on ageassociated changes in $\mathrm{PGF}_{2 \alpha}$ in humans and the effects of those changes on the development of cardiovascular disorders.

\section{6. $\mathrm{PGD}_{2}$}

$\mathrm{PGD}_{2}$ is synthesized by two $\mathrm{PGD}_{2}$ synthases (PGDSs) encoded by two unrelated genes. One is hematopoietic PGDS ( $\mathrm{H}-$ PGDS), and the other is lipocalin-type enzyme (L-PGDS) [138, Figure 1]. Both can be upregulated in response to an increase in fluid shear stress [153]. In most of the vasculatures, the level of $\mathrm{PGD}_{2}$ is very low or undetectable in some vascular beds [74], due to the low level of PGDSs [54, 64, 65, 84].

$\mathrm{PGD}_{2}$ has multiple receptors [154]. However, two $\mathrm{PGD}_{2}$ receptors (DP1 and DP2) have been most widely studied (Figure 1). Besides playing an important role in the central nervous and immune systems [154], $\mathrm{PGD}_{2}$ has functions in the vasculature. $\mathrm{PGD}_{2}$ can elicit endothelium-dependent relaxation through receptor activation [59] and acts as a vasodilator $[155,156]$. On the other hand, it can also act as a bronchoconstrictor [157-159]. Finally, $\mathrm{PGD}_{2}$ is an anticoagulant [160-163].

There is only one report on the effect of aging on PGDS and DP. While aging had no effect on L-PGDS, it caused a 5fold increase in H-PGDS mRNA in aged rat aorta endothelial cells [84]. Age had no apparent effect on DP [84]. H-PGDS is 3-fold higher in aorta endothelial cells from SHRs versus WKY rats, whereas L-PGDS is decreased in these cells in SHRs versus WKY rats [84]. In the smooth muscle cells from the same aorta preparations, DP mRNA was measured to be 3-fold higher in SHRs as compared with WKY rats [84].

\section{7. $\mathbf{T x A} \mathbf{A}_{2}$}

$\mathrm{TxA}_{2}$ is mainly produced in the platelets $[100,101]$. It is also synthesized in the vasculature, the endothelium, and smooth muscles by $\mathrm{TxA}_{2}$ synthase (TXS) [49, Figure 1]. However, the amount of $\mathrm{TxA}_{2}$ in the endothelium is much lower than the amount of $\mathrm{PGI}_{2}[54,97,107-110,125]$. Consistently, the expression level of the TXS is much lower than that of PGIS $[54,64,65,84]$.

There are two types of $\mathrm{TxA}_{2}$ receptors (TP) denoted, $\mathrm{TPa}$ and $\mathrm{TPb}$. TP interacts with $\mathrm{TxA}_{2}$ and other PGs, although $\mathrm{TxA}_{2}$ is the most potent agonist [54, 164, Figure 1]. TP appears to be the main receptor of $\mathrm{PGH}_{2}[25,26,90-$ 97]. Deletion of TP receptors has provided insights into their physiological function. For example, TP knochout mice exhibit decreased vascular proliferation and platelet activation in response to intimal lesions [165]. These animals also experience delays in atherogenesis [166]. TP deletion also prevents angiotensin-II- and L-NAME-induced hypertension and associated cardiac hypertrophy [167].

$\mathrm{TxA}_{2}$ elicits diverse physiological/pathophysiological reactions, including platelet aggregation and vascular smooth muscle contraction [49]. Activation of platelet aggregation 
TABle 1: Age-associated changes in PGs and $\mathrm{TxA}_{2}$ and their synthases and receptors.

\begin{tabular}{|c|c|c|c|c|}
\hline Entity & Tissue & Age & Change & References \\
\hline COX1/2 (hum, r, m) & Mesenteric microvessels & Adult, aged & Increase & $\begin{array}{c}21,29,33, \\
34,42,63, \\
84-86]\end{array}$ \\
\hline $\mathrm{PGI}_{2}$ (hum) & Blood & Adolescent, aged & Decrease & {$[112,116]$} \\
\hline PGIS (r) & Aorta, coronary artery in heart & Adults, aged & Increase & $\begin{array}{c}{[85,86,} \\
110,120]\end{array}$ \\
\hline IP (r) & Aorta & Adults, aged & Decrease & $\begin{array}{c}{[84,85} \\
121]\end{array}$ \\
\hline $\mathrm{PGE}_{2}(\mathrm{r})$ & Coronary artery in heart & Aged & Increase & [120] \\
\hline cPGES (r), & Aorta & Old adult & $\mathrm{N} / \mathrm{S}$ & {$[84]$} \\
\hline mPGES-1 (r) & Aorta & Old adult & $\mathrm{N} / \mathrm{S}$ & {$[84]$} \\
\hline mPGES-2 (r) & Aorta & Old adult & Increase & {$[84]$} \\
\hline EP1-3 (r) & Aorta & Old adult & $\mathrm{N} / \mathrm{S}$ & {$[84]$} \\
\hline EP4 (r) & Aorta & Old adult & Increase & {$[84]$} \\
\hline $\mathrm{PGF}_{2 \alpha}$ (ham, r) & Aorta & Aged & Increase & {$[110,148]$} \\
\hline PGFS (r) & Aorta & Old adult & Increase & [84] \\
\hline $\mathrm{FP}(\mathrm{r})$ & Aorta & Old adult & $\mathrm{N} / \mathrm{S}$ & {$[84]$} \\
\hline PGDS (r) & Aorta & Old adult & Increase & {$[84]$} \\
\hline $\mathrm{DP}(\mathrm{r})$ & Aorta & Old adult & $\mathrm{N} / \mathrm{S}$ & {$[84]$} \\
\hline $\mathrm{TxA}_{2}(\mathrm{r})$ & Aorta or mesenteric artery & & Increase & $\begin{array}{c}{[42,86} \\
172]\end{array}$ \\
\hline TXS (r) & Aorta & Old adult & Increase & [84] \\
\hline $\mathrm{TP}(\mathrm{r})$ & Aorta & Old adult & $\mathrm{N} / \mathrm{S}$ & {$[84]$} \\
\hline
\end{tabular}

hum: human; ham: hamster; r: rat; m: mouse; N/S: not significant.

Definition of age groups: human, adolescent, 13-19 years; adult, 20-60 years; aged, $>60$ years. Hamster, aged, >18 months. Rat, young adult, 3-6 months; old adult, $6-18$ months; aged $>24$ months.

is thought to be the dominant biological function of $\mathrm{TxA}_{2}$. $\mathrm{TxA}_{2}$ causes platelet shape change, aggregation, and secretion, which promotes thrombus formation and thrombosis [168-171]. Thrombosis can cause acute myocardial infarction and atherogenesis [166, 171-174]. TxA 2 -induced contraction effects are variable, depending on the specific vascular beds examined and the agent used to induce contraction $[116,175,176]$. The majority of reports coincide with the view that the contraction induced by endotheliumderived $\mathrm{TxA}_{2}$ is weak, because inhibitors of TXS do not induce relaxation $[91,92,96,176]$. Contraction effects are likely mediated by TP activated by $\mathrm{PGH}_{2}$ because inhibitors of PGHSs and TP induce relaxation $[91,92,96,175,176]$.

Several publications reported a $2-5$-fold increase in $\mathrm{TxA}_{2}$ in aorta or mesenteric arteries of aged rats as compared to that of young rats $[42,86,172]$. Consistently, Tang and Vanhoutte reported a 4-fold increase in TXS mRNA [84]. In contrast, a single investigation of age-dependence of $\mathrm{TxA}_{2}$ did not find any significant difference in $\mathrm{TxA}_{2}$ between young and aged rat aortas [110]. Aging did not show any significant effect on rat aorta TP mRNA [84].

An increased production of $\mathrm{TxA}_{2}$ has been found in patients and animal models of several cardiovascular diseases including unstable angina [177], experimental myocardial ischemia and infarction [178], cerebral vasospasm, pregnancy induced hypertension $[179,180]$, and congenital heart disease [116]. $\mathrm{TxA}_{2}$ levels reported in those studies are systemic, rather than endothelial. In endothelium, there is no difference in aorta $\mathrm{TxA}_{2}$ between SHRs and WKY rats $[54,64,65,87]$. However, TXS mRNA is doubled in the aorta endothelium of SHRs versus WKY rats [84]. Age-related changes in TP have not been found $[84,181]$.

In summary (Table 1), aging has been consistently shown to cause severalfold increase in COXs, that is, the synthesis of $\mathrm{PGH}_{2}[29,42,63,84-86]$. Aging probably reduces $\mathrm{PGI}_{2}$, the predominant PG in the endothelium [112, 115-118, 182], though it is not certain and requires more work. Aging has been shown, or has the potential, to change other PGs in the endothelium. However, because the level of $\mathrm{PGI}_{2}$ is $10-100$ fold higher than that of the rest of PGs, the shift of PG profile in the endothelium during aging will be predominantly determined by $\mathrm{PGI}_{2}$ and untransformed $\mathrm{PGH}_{2}$. $\mathrm{PGI}_{2}$ and $\mathrm{PGH}_{2}$ have opposing effects on vessels and platelets. The net result of the effects of aging will be a shift toward a proconstrictive mediator profile, as shown in Figure 2.

\section{Association of Prostaglandin and Cardiovascular Disorders in Aging}

Associated with this shift are several cardiovascular disorders including hypertension, atherosclerosis, myocardial ischemia, myocardial infarction, and stroke (Figure 2(b)). 


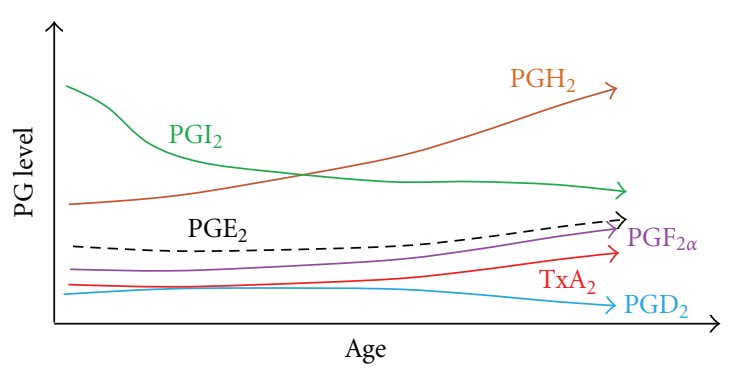

(a)

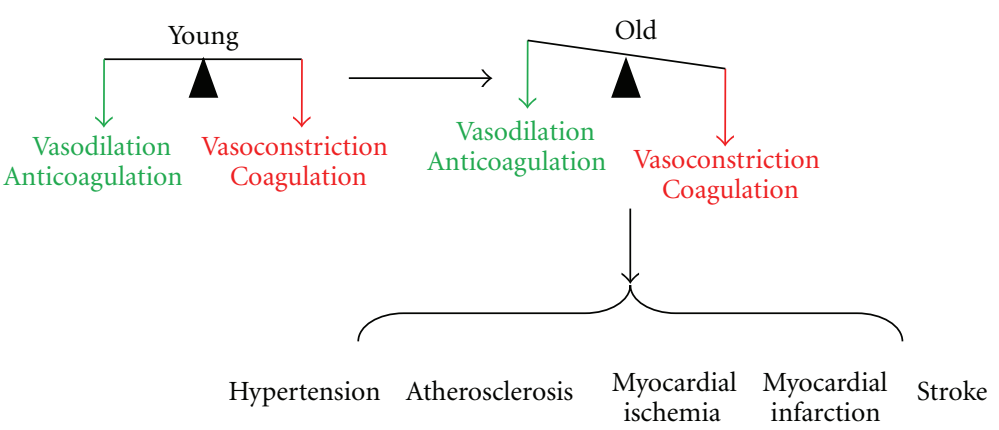

(b)

FIgure 2: Age-shifted PG profile (a) and vasoaction (b). (a) As age advances, most of the PGs and TxA $\mathrm{A}_{2}$ increase, whereas PGI 2 decreases. (b) The age shifts PG profile toward vasoconstriction and coagulation causing several cardiovascular disorders.

TABle 2: Prostaglandin-related pharmacological agents in the treatment of cardiovascular diseases.

\begin{tabular}{|c|c|c|c|}
\hline Modulator & Drugs (trade name) & Clinical application & References \\
\hline $\mathrm{PGI}_{2}$ and its stable analogues & $\begin{array}{l}\text { Epoprostenol sodium (Flolan), Beraprost } \\
\text { sodium (Procyclin), Iloprost (Ventavis), } \\
\text { Treprostinil (Remodulin) }\end{array}$ & $\begin{array}{l}\text { Primary pulmonary hypertension, } \\
\text { pulmonary arterial hypertension }\end{array}$ & [200-207] \\
\hline $\mathrm{PGE}_{2}$ and its analogues & Dinoprostone, Viprostol & Congenital heart disease & $\begin{array}{l}{[208-210,214-} \\
217]\end{array}$ \\
\hline TXS inhibitors & $\begin{array}{l}\text { Dazoxiben, Camonagrel, Picotamide } \\
\text { (Dusodril) }\end{array}$ & Thrombosis, atherosclerosis, arrhythmias & {$[218-226]$} \\
\hline TP inhibitors & Picotamide, S18886 (Triplion) & $\begin{array}{l}\text { Thrombosis, atherosclerosis, ischemic } \\
\text { stroke, myocardial infarction }\end{array}$ & {$[84,223-227]$} \\
\hline COX1 inhibitor & Aspirin & $\begin{array}{l}\text { Thrombosis, atherosclerosis, ischemic } \\
\text { stroke, myocardial infarction }\end{array}$ & {$[231-235]$} \\
\hline
\end{tabular}

Reduced ratio of $\mathrm{PGI}_{2} / \mathrm{TxA}_{2}$ was observed in elderly hypertensive patients [183-186]. Age impaired $\mathrm{PGI}_{2}$ synthesis $[84,187]$ is associated with hypertension [84], progression of atherosclerotic lesions [188], and increased thrombotic risk and heart failure [189, 190]. In addition, aging not only reduces the expression of IP [84], but also reduces the sensitivity of IP $[182,191]$. These factors might contribute to the progression of atherosclerosis, as mice with deleted IP [192, 193] and human patients with a dysfunctional prostacyclin IP receptor mutation [194] show accelerated atherothrombosis [97].

On the other hand, aging induces TXS [84]. Higher concentrations of $\mathrm{TxA}_{2}$ are observed in serum or urine in several age-related and hypertensive diseases [185, 186, 195]. In the atherosclerotic coronary artery, the density of TP receptor is increased [171]. Aging-increased $\mathrm{TxA}_{2}$, together with induced TP in the atherosclerotic coronary artery, accelerates arterial atherosclerosis, leading to myocardial infarction [191]. The TP-mediated signaling can also be triggered by $\mathrm{PGH}_{2}$. Age increases COX1/2 in animals and human $[21,29,33,34,42,63,84-86]$ and thereby increases $\mathrm{PGH}_{2}$ production. Age-increased expression of COX-2 in coronary, carotid, and femoral arteries is associated with human atherosclerosis [196-199].

\section{Therapeutics That Modulate Prostaglandins in Cardiovascular Disorders}

Because prostaglandins and thromboxane are such important factors in endothelium functions and therefore in the physiology and pathology of the vascular system, numerous pharmacological agents that target these factors have been developed to mitigate cardiovascular diseases. As listed in Table 2, prostacyclin $\left(\mathrm{PGI}_{2}\right)$ and analogues are used clinically to treat hypertension, especially pulmonary hypertension [75, 200-202]. They are also used to inhibit arterial thrombosis and ameliorate myocardial ischemia [203-207]. Although the vascular actions of $\mathrm{PGE}_{2}$ are complex, $\mathrm{PGE}_{2}$ and analogues are used to reduce blood pressure and to alleviate congestive heart failure [208-210], owing to their ability to stimulate renin release and natriuresis and diuresis [211213]. $\mathrm{PGE}_{2}, \mathrm{PGE}_{1}$, and their analogues are more often used to maintain the patency of the ductus arteriosus in infants with congenital heart disease [214-217]. Antagonists of TXS and TP are potent antithrombosis agents and used to treat atherosclerosis, myocardial ischemia, and stroke [218-227].

The underlying principle of the design of these drugs is to selectively increase the effects of vasodilators and anticoagulators and to selectively reduce the effects of vasoconstrictors and coagulators by modulating the amount of ligands, synthases, or receptors of a specific eicosanoid. Because prostaglandins and thromboxane $\mathrm{A}_{2}$ are from the same precursor but elicit opposing effects, selectivity is crucial in the design of these therapeutics. Nonselective inhibition of the upstream synthases, COX1 and COX2, can result in undesirable side effects including hypertension, manifestation of myocardial ischemia, and increased incidents of acute myocardial infarction and stroke, which occur more often in the elderly [104, 228-230]. 
Intriguingly, low dose of aspirin, an inhibitor of COX1, is popularly used in the prevention of cardiovascular diseases [231-233]. Aspirin covalently acetylates a specific serine moiety (serine 530 of COX-1 and serine 516 of COX-2) $[234,235]$, and its binding to COX1 is about 170 -fold stronger than that to COX-2 [236]. Thus, aspirin is a covalent inhibitor of COX1 inactivating it irreversibly. $\mathrm{TxA}_{2}$ is mainly produced in platelets $[100,101]$, whereas $\mathrm{PGI}_{2}$ is mainly produced by endothelial cells [51, 57]. Different from most other cell types, platelets do not possess nuclei, which are required for protein synthesis. While COX1 can be regenerated in other cells, such as endothelial cells, COX1 cannot be regenerated in platelets. Nor can COX1 activity be recovered after inactivation by aspirin. Therefore, low dose of aspirin irreversibly and selectively inhibits $\mathrm{TxA}_{2}$ production in platelets.

However, new platelets are constantly formed, and $\mathrm{TxA}_{2}$ is persistently produced [237], which leads to a need for continuous dosing to constantly inhibit COX1. Aspirin resistance is a common clinical phenomenon [238] and has been observed for more than twenty five years [239]. Aspirin resistant patients, partially due to inherited polymorphisms in COX1 [240, 241], have a nearly 4-fold increase in risk of suffering a vascular event compared with aspirin responders [242-244]. As an alternative to aspirin therapy, antagonists of TXS and TP, which can also be combined with aspirin, have been applied to ameliorate thrombosis and prevent cardiovascular diseases [226].

\section{Conclusion and Perspective}

The incidence and prevalence of cardiovascular diseases increase with advancing age, to the extent that age has been identified as the dominant risk factor for these pathologies $[2,4-6]$. It is well established that PGs are powerful endogenous vasodilators and vasoconstrictors and platelet aggregators, playing important roles in regulating homeostasis in vascular systems. Although limited, the current analysis of the literature suggests that there is a modified PG profile associated with age and indicates that age has significant effects on the abundance of PGs, their synthesis, as well as their signaling transduction pathways. Aging-modulated PG profile offers a potentially important molecular mechanism underlying age-dependent endothelial dysfunction and ageassociated cardiovascular diseases. Knowledge of age-associated PGs profile changes can be important for designing new pharmacological interventions to prevent or slow down age-associated cardiovascular diseases. Given their biological roles, improved investigation of age-associated changes in PG synthesis, metabolism, and signaling in all major vascular beds is needed.

It is clearly difficult to obtain human vascular tissues to determine age associated changes. Surrogate tissues and fluids such as human blood or urine are plentiful but are of limited value for assessing tissue-specific effects. Defining the relationship between PGs, particularly $\mathrm{PGI}_{2}$ and $\mathrm{PGH}_{2}$, in vascular tissues and the amounts in blood or urine in animal models could be helpful to interpret PG profiles in humans. Technical challenges exist due to metabolite instability. For example, $\mathrm{PGH}_{2}$ is transformed to other PGs and is biologically important in its own right, but untransformed $\mathrm{PGH}_{2}$ is difficult to measure $[98,245]$. The development of user-friendly methods could facilitate acquiring these measurements $[91,98,245]$. For example, $\mathrm{PGH}_{2}$ can be instantly reduced to 12-heptadecatrienoic acid (12-HHT) by $\mathrm{FeCl}_{2}$ $[91,98,245] .12-\mathrm{HHT}$ is stable and inactive and measurable $[91,98,245]$. Therefore, total $\mathrm{PGH}_{2}$ can be measured as 12HHT. A relatively mild reducing agent, $\mathrm{SnCl}_{2}$, can reduce untransformed $\mathrm{PGH}_{2}$ to $\mathrm{PGF}_{2 \alpha}$. Untransformed $\mathrm{PGH}_{2}$ can be calculated by subtracting the estimate of $\mathrm{PGF}_{2 \alpha}$ in samples without $\mathrm{SnCl}_{2}$ from the corresponding estimate in samples with $\mathrm{SnCl}_{2}[91,98,125]$. Alternatively, epidemiological approaches could avoid these technical difficulties and offer valuable genetic information. Haplotype analyses have revealed that several polymorphisms in COX, PGIS, and IP are associated with age and cardiovascular diseases [246-250].

Research on an important aspect of age-associated changes in PGs is largely absent in the literature; that of age-associated effects on PG metabolism. One of the most important features of PGs is rapid clearance. Most PGs are metabolized to inactive forms within 1-3 minutes [119, 251], and consequently their signaling is terminated within that time frame. This is due to an effective and efficient metabolism system mainly composed of prostaglandin transporter (PGT) and 15-hydroxyprostaglandin dehydrogenase (15-PGDH) [252]. Both PGT and 15-PGDH have been shown to regulate PG degradation $[245,253,254]$. Thus far, there have been no reports on the influence of age on PG metabolism.

In conclusion, $\mathrm{PGs}$ and $\mathrm{TxA}_{2}$ play critical roles in many important events involved in the normal functions of vascular system, including vasodilation, vasoconstriction, platelet aggregation, and inflammation. Although these eicosanoids were discovered in the 1970s, the research into ageassociated shifts of the PG profile has just begun. Age-associated alterations in PG profiles are not only interesting, but also important in defining the molecular mechanisms of ageassociated cardiovascular pathological conditions and informing strategic and personalized prevention and cure of those diseases.

\section{Acknowledgment}

Support for this project was provided by the American Heart Association (0735066N).

\section{References}

[1] http://www.who.int/mediacentre/factsheets/fs317/en/index .html.

[2] J. R. Docherty, "Cardiovascular responses in ageing: a review," Pharmacological Reviews, vol. 42, no. 2, pp. 103-125, 1990.

[3] A. M. Zeiher, H. Drexler, B. Saurbier, and H. Just, "Endothelium-mediated coronary blood flow modulation in humans: effects of age, atherosclerosis, hypercholesterolemia, and hypertension," Journal of Clinical Investigation, vol. 92, no. 2, pp. 652-662, 1993. 
[4] R. P. Brandes, I. Fleming, and R. Busse, "Endothelial aging," Cardiovascular Research, vol. 66, no. 2, pp. 286-294, 2005.

[5] E. G. Lakatta and D. Levy, "Arterial and cardiac aging: major shareholders in cardiovascular disease enterprises: part I: aging arteries: a "set up" for vascular disease," Circulation, vol. 107, no. 1, pp. 139-146, 2003.

[6] P. M. Rothwell, A. J. Coull, L. E. Silver et al., "Populationbased study of event-rate, incidence, case fatality, and mortality for all acute vascular events in all arterial territories (Oxford Vascular Study)," Lancet, vol. 366, no. 9499, pp. 1773-1783, 2005.

[7] L. Jayakody, T. Kappagoda, M. P. Senaratne, and A. B. Thomson, "Impairment of endothelium-dependent relaxation: an early marker for atherosclerosis in the rabbit," British Journal of Pharmacology, vol. 94, no. 2, pp. 335-346, 1988.

[8] H. L. Elliott, "Endothelial dysfunction in cardiovascular disease: risk factor, risk marker, or surrogate end point?" Journal of Cardiovascular Pharmacology, vol. 32, supplement 3, pp. S74-S77, 1998.

[9] R. Fathi, B. Haluska, N. Isbel, L. Short, and T. H. Marwick, "The relative importance of vascular structure and function in predicting cardiovascular events," Journal of the American College of Cardiology, vol. 43, no. 4, pp. 616-623, 2004.

[10] G. B. Mancini, "Vascular structure versus function: is endothelial dysfunction of independent prognostic importance or not?" Journal of the American College of Cardiology, vol. 43, no. 4, pp. 624-628, 2004.

[11] M. D. Herrera, C. Mingorance, R. Rodríguez-Rodríguez, and M. Alvarez de Sotomayor, "Endothelial dysfunction and aging: an update," Ageing Research Reviews, vol. 9, no. 2, pp. 142-152, 2010.

[12] R. F. Furchgott and J. V. Zawadzki, "The obligatory role of endothelial cells in the relaxation of arterial smooth muscle by acetylcholine," Nature, vol. 288, no. 5789, pp. 373-376, 1980.

[13] J. Davignon and P. Ganz, "Role of endothelial dysfunction in atherosclerosis," Circulation, vol. 109, no. 23, pp. III27-III32, 2004.

[14] D. S. Celermajer, K. E. Sorensen, D. J. Spiegelhalter, D. Georgakopoulos, J. Robinson, and J. E. Deanfield, "Aging is associated with endothelial dysfunction in healthy men years before the age-related decline in women," Journal of the American College of Cardiology, vol. 24, no. 2, pp. 471-476, 1994.

[15] S. Taddei, A. Virdis, P. Mattei et al., "Aging and endothelial function in normotensive subjects and patients with essential hypertension," Circulation, vol. 91, no. 7, pp. 1981-1987, 1995.

[16] S. Taddei, A. Virdis, P. Mattei et al., "Hypertension causes premature aging of endothelial function in humans," Hypertension, vol. 29, no. 3, pp. 736-743, 1997.

[17] K. Egashira, T. Inou, Y. Hirooka et al., "Effects of age on endothelium-dependent vasodilation of resistance coronary artery by acetylcholine in humans," Circulation, vol. 88, no. 1, pp. 77-81, 1993.

[18] C. F. Küng and T. F. Lüscher, "Different mechanisms of endothelial dysfunction with aging and hypertension in rat aorta," Hypertension, vol. 25, no. 2, pp. 194-200, 1995.

[19] M. Gerhard, M. A. Roddy, S. J. Creager, and M. A. Creager, "Aging progressively impairs endothelium-dependent vasodilation in forearm resistance vessels of humans," Hypertension, vol. 27, no. 4, pp. 849-853, 1996.
[20] I. Eskurza, K. D. Monahan, J. A. Robinson, and D. R. Seals, "Effect of acute and chronic ascorbic acid on flow-mediated dilatation with sedentary and physically active human ageing," Journal of Physiology, vol. 556, no. 1, pp. 315-324, 2004.

[21] L. Rodríguez-Mañas, S. Vallejo, P. López-Dóriga et al., "Endothelial dysfunction in aged humans is related with oxidative stress and vascular inflammation," Aging Cell, vol. 8, no. 3, pp. 226-238, 2009.

[22] I. Shimizu and N. Toda, "Alterations with age of the response to vasodilator agents in isolated mesenteric arteries of the beagle," British Journal of Pharmacology, vol. 89, no. 4, pp. 769-778, 1986.

[23] H. Moritoki, E. Hosoki, and Y. Ishida, "Age-related decrease in endothelium-dependent dilator response to histamine in rat mesenteric artery," European Journal of Pharmacology, vol. 126, no. 1-2, pp. 61-67, 1986.

[24] K. Hongo, T. Nakagomi, N. F. Kassell et al., "Effects of aging and hypertension on endothelium-dependent vascular relaxation in rat carotid artery," Stroke, vol. 19, no. 7, pp. 892897, 1988.

[25] M. R. Hynes and S. P. Duckles, "Effect of increasing age on the endothelium-mediated relaxation of rat blood vessels in vitro," Journal of Pharmacology and Experimental Therapeutics, vol. 241, no. 2, pp. 387-392, 1987.

[26] T. Koga, Y. Takata, K. Kobayashi, S. Takishita, Y. Yamashita, and M. Fujishima, "Age and hypertension promote endothelium-dependent contractions to acetylcholine in the aorta of the rat," Hypertension, vol. 14, no. 5, pp. 542-548, 1989.

[27] J. Atkinson, R. Tatchum-Talom, and C. Capdeville-Atkinson, "Reduction of endothelial function with age in the mesenteric arterial bed of the normotensive rat," British Journal of Pharmacology, vol. 111, no. 4, pp. 1184-1188, 1994.

[28] M. Tominaga, K. Fujii, I. Abe, Y. Takata, K. Kobayashi, and M. Fujishima, "Hypertension and ageing impair acetylcholineinduced vasodilation in rats," Journal of Hypertension, vol. 12, no. 3, pp. 259-268, 1994.

[29] K. G. Stewart, Y. Zhang, and S. T. Davidge, "Aging increases PGHS-2-dependent vasoconstriction in rat mesenteric arteries," Hypertension, vol. 35, no. 6, pp. 1242-1247, 2000.

[30] M. Y. Abeywardena, L. T. Jablonskis, and R. J. Head, "Ageand hypertension-induced changes in abnormal contractions in rat aorta," Journal of Cardiovascular Pharmacology, vol. 40, no. 6, pp. 930-937, 2002.

[31] J. M. Muller-Delp, S. A. Spier, M. W. Ramsey, and M. D. Delp, "Aging impairs endothelium-dependent vasodilation in rat skeletal muscle arterioles," American Journal of Physiology, vol. 283, no. 4, pp. H1662-H1672, 2002.

[32] E. Gomez, C. Schwendemann, S. Roger et al., "Aging and prostacyclin responses in aorta and platelets from WKY and SHR rats," American Journal of Physiology, vol. 295, no. 5, pp. H2198-H2211, 2008.

[33] M. È. Gendron, N. Thorin-Trescases, L. Villeneuve, and E. Thorin, "Aging associated with mild dyslipidemia reveals that COX-2 preserves dilation despite endothelial dysfunction," American Journal of Physiology, vol. 292, no. 1, pp. H451H458, 2007.

[34] M. Ė. Gendron and E. Thorin, "A change in the redox environment and thromboxane $\mathrm{A}_{2}$ production precede endothelial dysfunction in mice," American Journal of Physiology, vol. 293, no. 4, pp. H2508-H2515, 2007.

[35] C. C. Haudenschild, M. F. Prescott, and A. V. Chobanian, "Aortic endothelial and subendothelial cells in experimental 
hypertension and aging," Hypertension, vol. 3, no. 3, pp. 148153, 1981.

[36] C. C. Haudenschild and A. V. Chobanian, "Blood pressure lowering diminishes age-related changes in the rat aortic intima," Hypertension, vol. 6, no. 2, pp. I-62-I-68, 1984.

[37] E. E. Soltis, "Effect of age on blood pressure and membranedependent vascular responses in the rat," Circulation Research, vol. 61, no. 6, pp. 889-897, 1987.

[38] T. Koga, Y. Takata, K. Kobayashi, S. Takishita, Y. Yamashita, and M. Fujishima, "Ageing suppresses endothelium-dependent relaxation and generates contraction mediated by the muscarinic receptors in vascular smooth muscle of normotensive Wistar-Kyoto and spontaneously hypertensive rats," Journal of Hypertension, vol. 6, no. 4, pp. S243-S245, 1988.

[39] Y. Iwama, T. Kato, M. Muramatsu et al., "Correlation with blood pressure of the acetylcholine-induced endotheliumderived contracting factor in the rat aorta," Hypertension, vol. 19, no. 4, pp. 326-332, 1992.

[40] A. U. Ferrari, A. Radaelli, and M. Centola, "Aging and the cardiovascular system," Journal of Applied Physiology, vol. 95, no. 6, pp. 2591-2597, 2003.

[41] R. L. Matz and R. Andriantsitohaina, "Age-related endothelial dysfunction: potential implications for pharmacotherapy," Drugs and Aging, vol. 20, no. 7, pp. 527-550, 2003.

[42] R. L. Matz, M. A. de Sotomayor, C. Schott, J. C. Stoclet, and R. Andriantsitohaina, "Vascular bed heterogeneity in agerelated endothelial dysfunction with respect to $\mathrm{NO}$ and eicosanoids," British Journal of Pharmacology, vol. 131, no. 2, pp. 303-311, 2000.

[43] M. Barton, F. Cosentino, R. P. Brandes, P. Moreau, S. Shaw, and T. F. Lüscher, "Anatomic heterogeneity of vascular aging: role of nitric oxide and endothelin," Hypertension, vol. 30, no. 4, pp. 817-824, 1997.

[44] I. Fleming and R. Busse, "NO: the primary EDRF," Journal of Molecular and Cellular Cardiology, vol. 31, no. 1, pp. 5-14, 1999.

[45] M. R. Tschudi, M. Barton, N. A. Bersinger et al., "Effect of age on kinetics of nitric oxide release in rat aorta and pulmonary artery," Journal of Clinical Investigation, vol. 98, no. 4, pp. 899-905, 1996.

[46] W. L. Smith, "Localization of enzymes responsible for prostaglandin formation," in Handbook of Eicosanoids: Prostaglandins and Related Lipids, A. L. Wmlis, Ed., vol. IA, pp. 175-184, CRC Press, Boca Raton, Fla, USA, 1987.

[47] J. R. Weeks, "Prostaglandins," Annual Review of Pharmacology, vol. 12, pp. 317-336, 1972.

[48] R. I. Clyman, F. Mauray, C. Roman, and A. M. Rudolph, "PGE2 is a more potent vasodilator of the lamb ductus arteriosus than is either PGI2 or 6 keto PGF $(1 \alpha)$," Prostaglandins, vol. 16, no. 2, pp. 259-264, 1978.

[49] N. Nakahata, "Thromboxane $\mathrm{A}_{2}$ : physiology/pathophysiology, cellular signal transduction and pharmacology," Pharmacology and Therapeutics, vol. 118, no. 1, pp. 18-35, 2008.

[50] S. Moncada, R. Gryglewski, S. Bunting, and J. R. Vane, "An enzyme isolated from arteries transforms prostaglandin endoperoxides to an unstable substance that inhibits platelet aggregation,” Nature, vol. 263, no. 5579, pp. 663-665, 1976.

[51] S. Moncada, A. G. Herman, E. A. Higgs, and J. R. Vane, "Differential formation of prostacyclin (PGX or PGI2) by layers of the arterial wall. An explanation for the antithrombotic properties of vascular endothelium," Thrombosis Research, vol. 11, no. 3, pp. 323-344, 1977.
[52] S. P. Williams, G. W. Dorn 2nd, and R. M. Rapoport, "Prostaglandin I2 mediates contraction and relaxation of vascular smooth muscle," American Journal of Physiology, vol. 267, no. 2, pp. H796-H803, 1994.

[53] R. M. Rapoport and S. P. Williams, "Role of prostaglandins in acetylcholine-induced contraction of aorta from spontaneously hypertensive and Wistar-Kyoto rats," Hypertension, vol. 28, no. 1, pp. 64-75, 1996.

[54] P. Gluais, M. Lonchampt, J. D. Morrow, P. M. Vanhoutte, and M. Feletou, "Acetylcholine-induced endothelium-dependent contractions in the SHR aorta: the Janus face of prostacyclin," British Journal of Pharmacology, vol. 146, no. 6, pp. 834-845, 2005.

[55] S. Bunting, S. Gryglewski, S. Moncada, and J. R. Vane, "Arterial walls generate from prostaglandin endoperoxides a substance (prostaglandin X) which relaxes strips of mesenteric and coeliac arteries and inhibits platelet aggregation," Prostaglandins, vol. 12, no. 6, pp. 897-913, 1976.

[56] R. R. Gorman, F. A. Fitzpatrick, and O. V. Miller, "Reciprocal regulation of human platelet cAMP levels by thromboxane $\mathrm{A}_{2}$ and prostacyclin," Advances in Cyclic Nucleotide Research, vol. 9, pp. 597-609, 1978.

[57] S. Moncada and J. R. Vane, "The role of prostacyclin in vascular tissue," Desty's Federal Procedure, vol. 38, no. 1, pp. 66-71, 1979.

[58] H. Shimokawa, N. A. Flavahan, R. R. Lorenz, and P. M. Vanhoutte, "Prostacyclin releases endothelium-derived relaxing factor and potentiates its action in coronary arteries of the pig," British Journal of Pharmacology, vol. 95, no. 4, pp. 1197-1203, 1988.

[59] D. Abran, D. R. Varma, and S. Chemtob, "Regulation of prostanoid vasomotor effects and receptors in choroidal vessels of newborn pigs," American Journal of Physiology, vol. 272, no. 3, pp. R995-R1001, 1997.

[60] Z. S. Katusic, J. T. Shepherd, and P. M. Vanhoutte, "Endothelium-dependent contractions to calcium ionophore A23187, arachidonic acid and acetylcholine in canine basilar arteries," Stroke, vol. 19, no. 4, pp. 476-479, 1988.

[61] H. Shirahase, H. Usui, K. Kurahashi, M. Fujiwara, and K. Fukui, "Endothelium-dependent contraction induced by nicotine in isolated canine basilar artery-possible involvement of a thromboxane A (TXA2) like substance," Life Sciences, vol. 42, no. 4, pp. 437-445, 1988.

[62] S. Taddei and P. M. Vanhoutte, "Role of endothelium in endothelin-evoked contractions in the rat aorta," Hypertension, vol. 21, no. 1, pp. 9-15, 1993.

[63] T. Ge, H. Hughes, D. C. Junquero, K. K. Wu, P. M. Vanhoutte, and C. M. Boulanger, "Endothelium-dependent contractions are associated with both augmented expression of prostaglandin $\mathrm{H}$ synthase- 1 and hypersensitivity to prostaglandin $\mathrm{H}_{2}$ in the SHR aorta," Circulation Research, vol. 76, no. 6, pp. 1003-1010, 1995.

[64] P. Gluais, J. Paysant, C. Badier-Commander, T. Verbeuren, P. M. Vanhoutte, and M. Félétou, "In SHR aorta, calcium ionophore A-23187 releases prostacyclin and thromboxane $\mathrm{A}_{2}$ as endothelium-derived contracting factors," American Journal of Physiology, vol. 291, no. 5, pp. H2255-H2264, 2006.

[65] P. Gluais, P. M. Vanhoutte, and M. Félétou, "Mechanisms underlying ATP-induced endothelium-dependent contractions in the SHR aorta," European Journal of Pharmacology, vol. 556, no. 1-3, pp. 107-114, 2007.

[66] A. Hirao, K. Kondo, N. Inui, K. Umemura, K. Ohashi, and H. Watanabe, "Cyclooxygenase-dependent vasoconstricting 
factor(s) in remodelled rat femoral arteries," Cardiovascular Research, vol. 79, no. 1, pp. 161-168, 2008.

[67] J. Nakano, R. B. McCloy, and A. V. Prancan, "Circulatory and pulmonary airway responses to different mixtures of prostaglandins $\mathrm{E}_{2}$ and $\mathrm{F}_{2 \alpha}$ in dogs," European Journal of Pharmacology, vol. 24, no. 1, pp. 61-66, 1973.

[68] G. J. Dusting and J. R. Vane, "Some cardiovascular properties of prostacyclin (PGI2) which are not shared by PGE2," Circulation Research, vol. 46, no. 6, pp. I183-I187, 1980.

[69] J. Carter, J. A. Reynoldson, and G. D. Thorburn, "The effects of certain vasodilating prostaglandins on the coronary and hindlimb vascular beds of the conscious sheep," Comparative Biochemistry and Physiology, vol. 83, no. 2, pp. 401-406, 1986.

[70] U. Neisius, R. Olsson, R. Rukwied, G. Lischetzki, and M. Schmelz, "Prostaglandin $\mathrm{E}_{2}$ induces vasodilation and pruritus, but no protein extravasation in atopic dermatitis and controls," Journal of the American Academy of Dermatology, vol. 47, no. 1, pp. 28-32, 2002.

[71] S. J. Gray and S. Heptinstall, "The effects of PGE2 and CL 115,347, an antihypertensive PGE2 analogue, on human blood platelet behaviour and vascular contractility," European Journal of Pharmacology, vol. 114, no. 2, pp. 129-137, 1985.

[72] U. Förstermann, A. Mügge, U. Alheid, S. M. Bode, and J. C. Frölich, "Endothelium-derived relaxing factor (EDRF): a defence mechanism against platelet aggregation and vasospasm in human coronary arteries," European Heart Journal, vol. 10, supplement F, pp. 36-43, 1989.

[73] J. E. Fabre, M. Nguyen, K. Athirakul et al., "Activation of the murine EP3 receptor for PGE2 inhibits cAMP production and promotes platelet aggregation," Journal of Clinical Investigation, vol. 107, no. 5, pp. 603-610, 2001.

[74] W. L. Smith, "Prostaglandin biosynthesis and its compartmentation in vascular smooth muscle and endothelial cells," Annual Review of Physiology, vol. 48, pp. 251-262, 1986.

[75] X. Norel, "Prostanoid receptors in the human vascular wall," The Scientific World Journal, vol. 7, pp. 1359-1374, 2007.

[76] N. Singh, S. Prasad, D. R. Singer, and R. J. MacAllister, "Ageing is associated with impairment of nitric oxide and prostanoid dilator pathways in the human forearm," Clinical Science, vol. 102, no. 5, pp. 595-600, 2002.

[77] M. Wang, A. M. Zukas, Y. Hui, E. Ricciotti, E. Puré, and G. A. FitzGerald, "Deletion of microsomal prostaglandin E synthase-1 augments prostacyclin and retards atherogenesis," Proceedings of the National Academy of Sciences of the United States of America, vol. 103, no. 39, pp. 14507-14512, 2006.

[78] D. L. DeWitt, J. S. Day, W. K. Sonneburg, and W. L. Smith, "Concentrations of prostaglandin endoperoxide synthase and prostaglandin I2 synthase in the endothelium and smooth muscle of bovine aorta," Journal of Clinical Investigation, vol. 72, no. 6, pp. 1882-1888, 1983.

[79] R. Doroudi, L. M. Gan, L. Selin Sjögren, and S. Jern, "Effects of shear stress on eicosanoid gene expression and metabolite production in vascular endothelium as studied in a novel biomechanical perfusion model," Biochemical and Biophysical Research Communications, vol. 269, no. 1, pp. 257-264, 2000.

[80] C. D. Funk and G. A. FitzGerald, "COX-2 inhibitors and cardiovascular risk," Journal of Cardiovascular Pharmacology, vol. 50, no. 5, pp. 470-479, 2007.

[81] J. N. Topper, J. Cai, D. Falb, and M. A. Gimbrone Jr., "Identification of vascular endothelial genes differentially responsive to fluid mechanical stimuli: cyclooxygenase-2, manganese superoxide dismutase, and endothelial cell nitric oxide synthase are selectively up-regulated by steady laminar shear stress," Proceedings of the National Academy of Sciences of the United States of America, vol. 93, no. 19, pp. 10417$10422,1996$.

[82] M. Onodera, I. Morita, Y. Mano, and S. Murota, "Differential effects of nitric oxide on the activity of prostaglandin endoperoxide $\mathrm{H}$ synthase-1 and -2 in vascular endothelial cells," Prostaglandins Leukotrienes and Essential Fatty Acids, vol. 62, no. 3, pp. 161-167, 2000.

[83] D. W. Kawka, M. Ouellet, P. O. Hétu, I. I. Singer, and D. Riendeau, "Double-label expression studies of prostacyclin synthase, thromboxane synthase and COX isoforms in normal aortic endothelium," Biochimica et Biophysica Acta, vol. 1771, no. 1, pp. 45-54, 2007.

[84] E. H. Tang and P. M. Vanhoutte, "Gene expression changes of prostanoid synthases in endothelial cells and prostanoid receptors in vascular smooth muscle cells caused by aging and hypertension," Physiological Genomics, vol. 32, no. 3, pp. 409-418, 2008.

[85] Y. Numaguchi, M. Harada, H. Osanai et al., "Altered gene expression of prostacyclin synthase and prostacyclin receptor in the thoracic aorta of spontaneously hypertensive rats," Cardiovascular Research, vol. 41, no. 3, pp. 682-688, 1999.

[86] K. B. Kang, M. A. Rajanayagam, A. van der Zypp, and H. Majewski, "A role for cyclooxygenase in aging-related changes of $\beta$-adrenoceptor- mediated relaxation in rat aortas," Naunyn-Schmiedeberg's Archives of Pharmacology, vol. 375, no. 4, pp. 273-281, 2007.

[87] D. A. Graham and J. W. Rush, "Cyclooxygenase and thromboxane/prostaglandin receptor contribute to aortic endothelium-dependent dysfunction in aging female spontaneously hypertensive rats," Journal of Applied Physiology, vol. 107, no. 4, pp. 1059-1067, 2009.

[88] W. T. Wong, X. Y. Tian, F. P. Leung et al., "Bone morphogenic protein-4 impairs endothelial function through oxidative stress-dependent cyclooxygenase-2 upregulation: implications on hypertension," Circulation Research, vol. 107, no. 8, pp. 984-991, 2010.

[89] C. Qu, S. W. Leung, P. M. Vanhoutte, and R. Y. Man, "Chronic inhibition of nitric-oxide synthase potentiates endothelium-dependent contractions in the rat aorta by augmenting the expression of cyclooxygenase-2," Journal of Pharmacology and Experimental Therapeutics, vol. 334, no. 2, pp. 373-380, 2010.

[90] T. Kato, Y. Iwama, K. Okumura, H. Hashimoto, T. Ito, and T. Satake, "Prostaglandin $\mathrm{H}_{2}$ may be the endothelium-derived contracting factor released by acetylcholine in the aorta of the rat," Hypertension, vol. 15, no. 5, pp. 475-481, 1990.

[91] P. J. Pagano, L. Lin, W. C. Sessa, and A. Nasjletti, "Arachidonic acid elicits endothelium-dependent release from the rabbit aorta of a constrictor prostanoid resembling prostaglandin endoperoxides," Circulation Research, vol. 69, no. 2, pp. 396405, 1991.

[92] F. X. Dai, J. Skopec, A. Diederich, and D. Diederich, "Prostaglandin $\mathrm{H}_{2}$ and thromboxane $\mathrm{A}_{2}$ are contractile factors in intrarenal arteries of spontaneously hypertensive rats," Hypertension, vol. 19, no. 6, pp. 795-798, 1992.

[93] K. Shimizu, M. Muramatsu, Y. Kakegawa et al., "Role of prostaglandin $\mathrm{H}_{2}$ as an endothelium-derived contracting factor in diabetic state," Diabetes, vol. 42, no. 9, pp. 12461252, 1993.

[94] K. C. Kent, L. J. Collins, F. T. Schwerin, M. K. Raychowdhury, and J. A. Ware, "Identification of functional $\mathrm{PGH} 2 / \mathrm{TxA}_{2}$ 
receptors on human endothelial cells," Circulation Research, vol. 72, no. 5, pp. 958-965, 1993.

[95] H. Asano, K. Shimizu, M. Muramatsu et al., "Prostaglandin $\mathrm{H}_{2}$ as an endothelium-derived contracting factor modulates endothelin-1-induced contraction," Journal of Hypertension, vol. 12, no. 4, pp. 383-390, 1994.

[96] L. Lin, M. Balazy, P. J. Pagano, and A. Nasjletti, “Expression of prostaglandin $\mathrm{H}_{2}$-mediated mechanism of vascular contraction in hypertensive rats: relation to lipoxygenase and prostacyclin synthase activities," Circulation Research, vol. 74, no. 2, pp. 197-205, 1994.

[97] M. Félétou, T. J. Verbeuren, and P. M. Vanhoutte, "Endothelium-dependent contractions in SHR: a tale of prostanoid TP and IP receptors," British Journal of Pharmacology, vol. 156, no. 4, pp. 563-574, 2009.

[98] M. Hamberg and B. Samuelsson, "Prostaglandin endoperoxides. Novel transformations of arachidonic acid in human platelets," Proceedings of the National Academy of Sciences of the United States of America, vol. 71, no. 9, pp. 3400-3404, 1974.

[99] M. Hamberg, J. Svensson, T. Wakabayashi, and B. Samuelsson, "Isolation and structure of two prostaglandin endoperoxides that cause platelet aggregation," Proceedings of the $\mathrm{Na}$ tional Academy of Sciences of the United States of America, vol. 71, no. 2, pp. 345-349, 1974.

[100] S. Moncada, P. Needleman, S. Bunting, and J. R. Vane, "Prostaglandin endoperoxide and thromboxane generating systems and their selective inhibition," Prostaglandins, vol. 12, no. 3, pp. 323-335, 1976.

[101] P. Needleman, S. Moncada, S. Bunting, J. R. Vane, M. Hamberg, and B. Samuelsson, "Identification of an enzyme in platelet microsomes which generates thromboxane $\mathrm{A}_{2}$ from prostaglandin endoperoxides," Nature, vol. 261, no. 5561, pp. 558-560, 1976.

[102] N. A. Flavahan, "Balancing prostanoid activity in the human vascular system," Trends in Pharmacological Sciences, vol. 28, no. 3, pp. 106-110, 2007.

[103] B. F. Mcadam, F. Catella-Lawson, I. A. Mardini, S. Kapoor, J. A. Lawson, and G. A. Fitzgerald, "Systemic biosynthesis of prostacyclin by cyclooxygenase (COX)-2: the human pharmacology of a selective inhibitor of COX-2," Proceedings of the National Academy of Sciences of the United States of America, vol. 96, no. 1, pp. 272-277, 1999.

[104] G. E. Rovati, A. Sala, V. Capra, S. E. Dahlén, and G. Folco, "Dual COXIB/TP antagonists: a possible new twist in NSAID pharmacology and cardiovascular risk," Trends in Pharmacological Sciences, vol. 31, no. 3, pp. 102-107, 2010.

[105] K. K. Wu and J. Y. Liou, "Cellular and molecular biology of prostacyclin synthase," Biochemical and Biophysical Research Communications, vol. 338, no. 1, pp. 45-52, 2005.

[106] J. Y. Liou, S. K. Shyue, M. J. Tsai, C. L. Chung, K. Y. Chu, and K. K. Wu, "Colocalization of prostacyclin synthase with prostaglandin $\mathrm{H}$ synthase-1 (PGHS-1) but not phorbol esterinduced PGHS-2 in cultured endothelial cells," Journal of Biological Chemistry, vol. 275, no. 20, pp. 15314-15320, 2000.

[107] R. Brandt, A. Dembinska-Kiec, R. J. Gryglewski, and J. Nowak, "Release of prostacyclin from the human pulmonary vascular bed in response to cholinergic stimulation," Naunyn-Schmiedeberg's Archives of Pharmacology, vol. 325, no. 1, pp. 69-75, 1984.

[108] X. Norel, I. Haye-Legrand, C. Labat, J. Benveniste, and C. Brink, "Antigen-induced contraction of human isolated lung preparations passively sensitized with monoclonal IgE: effects of indomethacin," International Archives of Allergy and Applied Immunology, vol. 96, no. 4, pp. 368-375, 1991.

[109] C. J. Buzzard, S. L. Pfister, and W. B. Campbell, "Endothelium-dependent contractions in rabbit pulmonary artery are mediated by thromboxane $\mathrm{A}_{2}$," Circulation Research, vol. 72, no. 5, pp. 1023-1034, 1993.

[110] C. Heymes, A. Habib, D. Yang et al., "Cyclo-oxygenase-1 and -2 contribution to endothelial dysfunction in ageing," British Journal of Pharmacology, vol. 131, no. 4, pp. 804-810, 2000.

[111] R. A. Coleman, W. L. Smith, and S. Narumiya, "VIII. International union of pharmacology classification of prostanoid receptors: properties, distribution, and structure of the receptors and their subtypes," Pharmacological Reviews, vol. 46, no. 2, pp. 205-229, 1994.

[112] P. Kääpä, L. Viinikka, and O. Ylikorkala, "Plasma prostacyclin from birth to adolescence," Archives of Disease in Childhood, vol. 57, no. 6, pp. 459-461, 1982.

[113] J. M. Armstrong, N. Lattimer, S. Moncada, and J. R. Vane, "Comparison of the vasodepressor effects of prostacyclin and 6-oxo-prostaglandin F1 $\alpha$ with those of prostaglandin $\mathrm{E}_{2}$ in rats and rabbits," British Journal of Pharmacology, vol. 62, no. 1, pp. 125-130, 1978.

[114] Y. Cheng, M. Wang, Y. Yu, J. Lawson, C. D. Funk, and G. A. FitzGerald, "Cyclooxygenases, microsomal prostaglandin E synthase-1, and cardiovascular function," Journal of Clinical Investigation, vol. 116, no. 5, pp. 1391-1399, 2006.

[115] S. Fischer, C. Bernutz, H. Meier, and P. C. Weber, "Formation of prostacyclin and thromboxane in man as measured by the main urinary metabolites," Biochimica et Biophysica Acta, vol. 876, no. 2, pp. 194-199, 1986.

[116] I. Adatia, S. E. Barrow, P. D. Stratton, V. M. Miall-Allen, J. M. Ritter, and S. G. Haworth, "Thromboxane $\mathrm{A}_{2}$ and prostacyclin biosynthesis in children and adolescents with pulmonary vascular disease," Circulation, vol. 88, no. 5 I, pp. 2117-2122, 1993.

[117] O. Tokunaga, T. Yamada, J. I. Fan, and T. Watanabe, "Agerelated decline in prostacyclin synthesis by human aortic endothelial cells: qualitative and quantitative analysis," American Journal of Pathology, vol. 138, no. 4, pp. 941-949, 1991.

[118] K. Neubert, A. Haberland, I. Kruse, and I. Schimke, "The ratio of formation of prostacyclin/thromboxane $A_{2}$ in HUVEC decreased in each subsequent passage," Prostaglandins, vol. 54, no. 1, pp. 447-462, 1997.

[119] S. H. Ferreira and J. R. Vane, "Prostaglandins: their disappearance from and release into the circulation," Nature, vol. 216, no. 5118, pp. 868-873, 1967.

[120] A. Ishihata, T. Ogaki, T. Aita, and Y. Katano, "Role of prostaglandins in urotensin II-induced vasodilatation in the coronary arteries of aged rats," European Journal of Pharmacology, vol. 523, no. 1-3, pp. 119-126, 2005.

[121] W. T. Nicholson, B. Vaa, C. Hesse, J. H. Eisenach, and M. J. Joyner, "Aging Is Associated with reduced prostacyclinmediated dilation in the human forearm," Hypertension, vol. 53, no. 6, pp. 973-978, 2009.

[122] S. Hara, D. Kamei, Y. Sasaki, A. Tanemoto, Y. Nakatani, and M. Murakami, "Prostaglandin E synthases: understanding their pathophysiological roles through mouse genetic models," Biochimie, vol. 92, no. 6, pp. 651-659, 2010.

[123] B. Samuelsson, R. Morgenstern, and P. J. Jakobsson, "Membrane prostaglandin E synthase-1: a novel therapeutic target," Pharmacological Reviews, vol. 59, no. 3, pp. 207-224, 2007.

[124] A. V. Sampey, S. Monrad, and L. J. Crofford, "Microsomal prostaglandin E synthase-1: the inducible synthase for 
prostaglandin $\mathrm{E}_{2}$," Arthritis Research and Therapy, vol. 7, no. 3, pp. 114-117, 2005.

[125] M. Camacho, J. López-Belmonte, and L. Vila, "Rate of vasoconstrictor prostanoids released by endothelial cells depends on cyclooxygenase- 2 expression and prostaglandin I synthase activity," Circulation Research, vol. 83, no. 4, pp. 353-365, 1998.

[126] T. Yang, "Microsomal prostaglandin e synthase-1 and blood pressure regulation," Kidney International, vol. 72, no. 3, pp. 274-278, 2007.

[127] M. Wang, A. M. Zukas, Y. Hui, E. Ricciotti, E. Puré, and G. A. FitzGerald, "Deletion of microsomal prostaglandin E synthase- 1 augments prostacyclin and retards atherogenesis," Proceedings of the National Academy of Sciences of the United States of America, vol. 103, no. 39, pp. 14507-14512, 2006.

[128] Y. Sugimoto and S. Narumiya, "Prostaglandin E receptors," Journal of Biological Chemistry, vol. 282, no. 16, pp. 1161311617, 2007.

[129] A. Alfranca, M. A. Iñiguez, M. Fresno, and J. M. Redondo, "Prostanoid signal transduction and gene expression in the endothelium: role in cardiovascular diseases," Cardiovascular Research, vol. 70, no. 3, pp. 446-456, 2006.

[130] H. Shio, J. Shaw, and P. Ramwell, "Relation of cyclic AMP to the release and actions of prostaglandins," Annals of the New York Academy of Sciences, vol. 185, pp. 327-335, 1971.

[131] E. W. Salzman, P. C. Kensler, and L. Levine, 'Cyclic 3',5'adenosine monophosphate in human blood platelets. IV. Regulatory role of cyclic amp in platelet function," Annals of the New York Academy of Sciences, vol. 201, pp. 61-71, 1972.

[132] H. J. Weiss, A. L. Willis, D. Kuhn, and H. Brand, "Prostaglandin $\mathrm{E}_{2}$ potentiation of platelet aggregation induced by LASS endoperoxide: absent in storage pool disease, normal after aspirin ingestion," British Journal of Haematology, vol. 32, no. 2, pp. 257-272, 1976.

[133] A. Morimoto, K. Morimoto, T. Watanabe, Y. Sakata, and N. Murakami, "Does an increase in prostaglandin $\mathrm{E}_{2}$ in the blood circulation contribute to a febrile response in rabbits?" Brain Research Bulletin, vol. 29, no. 2, pp. 189-192, 1992.

[134] S. Bergstorem, R. Ryhage, B. Samuelsson, and J. Sjoevall, "Prostaglandins and related factors. 15. The structures of prostaglandin E1, F1- $\alpha$, and F1- $\beta$," The Journal of Biological Chemistry, vol. 238, pp. 3555-3564, 1963.

[135] M. J. Dunn, J. F. Liard, and F. Dray, "Basal and stimulated rates of renal secretion and excretion of prostaglandings $\mathrm{E}_{2}$, Falpha, and 13, 14-dihydro-15-keto Falpha in the dog," Kidney International, vol. 13, no. 2, pp. 36-43, 1978.

[136] T. E. Liston and L. J. Roberts II, "Transformation of prostaglandin D2 to $9 \alpha, 11 \beta$-(15S)-trihydroxyprosta-(5Z,13E)dien-1-oic acid $(9 \alpha, 11 \beta$-prostaglandin F2): a unique biologically active prostaglandin produced enzymatically in vivo in humans," Proceedings of the National Academy of Sciences of the United States of America, vol. 82, no. 18, pp. 6030-6034, 1985.

[137] C. R. Beasley, C. Robinson, and R. L. Featherstone, " $9 \alpha, 11 \beta$ prostaglandin F2, a novel metabolite of prostaglandin D2 is a potent contractile agonist of human and guinea pig airways," Journal of Clinical Investigation, vol. 79, no. 3, pp. 978-983, 1987.

[138] R. J. Helliwell, L. F. Adams, and M. D. Mitchell, "Prostaglandin synthases: recent developments and a novel hypothesis," Prostaglandins Leukotrienes and Essential Fatty Acids, vol. 70, no. 2, pp. 101-113, 2004.
[139] M. Fukunaga, N. Makita, L. J. Roberts 2nd, J. D. Morrow, K. Takahashi, and K. F. Badr, "Evidence for the existence of F2isoprostane receptors on rat vascular smooth muscle cells," American Journal of Physiology, vol. 264, no. 6, pp. C1619C1624, 1993.

[140] M. Abramovitz, Y. Boie, T. Nguyen et al., "Cloning and expression of a cDNA for the human prostanoid FP receptor," Journal of Biological Chemistry, vol. 269, no. 4, pp. 26322636, 1994.

[141] S. Lake, H. Gullverg, J. Wahlqvist et al., "Cloning of the rat and human prostaglandin F2 alpha receptors and the expression of the rat prostaglandin F2 alpha receptor," FEBS Letters, vol. 355, no. 3, pp. 317-325, 1994.

[142] K. Sakamoto, T. Ezashi, K. Miwa et al., "Molecular cloning and expression of a cDNA of the bovine prostaglandin F2 alpha receptor," Advances in Prostaglandin, Thromboxane, and Leukotriene Research, vol. 23, pp. 259-261, 1995.

[143] Y. Sugimoto, K. Hasumoto, T. Namba et al., "Cloning and expression of a cDNA for mouse prostaglandin F receptor," Journal of Biological Chemistry, vol. 269, no. 2, pp. 13561360, 1994.

[144] J. Csepli and A. I. Csapo, "The effect of the prostaglandin F2 $\alpha$ analogue ICI 81008 on uterine small arteries and on blood pressure," Prostaglandins, vol. 10, no. 4, pp. 689-697, 1975.

[145] A. N. Hata and R. M. Breyer, "Pharmacology and signaling of prostaglandin receptors: multiple roles in inflammation and immune modulation," Pharmacology and Therapeutics, vol. 103, no. 2, pp. 147-166, 2004.

[146] E. M. Smyth, T. Grosser, M. Wang, Y. Yu, and G. A. FitzGerald, "Prostanoids in health and disease," Journal of Lipid Research, vol. 50, pp. S423-428, 2009.

[147] S. L. Wong, F. P. Leung, P. Vanhoutte, and Y. Huang, "Endothelium-dependent contractions in hamster aorta: the essential role of COX-2 and prostaglandin-2 $\alpha$," Basic, Basic and Clinical Pharmacology and Toxicology, vol. 102, pp. 15-15, 2008.

[148] S. L. Wong, F. P. Leung, C. W. Lau et al., "Cyclooxygenase-2derived prostaglandin F $2 \alpha$ mediates endothelium-dependent contractions in the aortae of hamsters with increased impact during aging," Circulation Research, vol. 104, no. 2, pp. 228 235, 2009.

[149] Y. Yu, M. B. Lucitt, J. Stubbe et al., "Prostaglandin F2 $\alpha$ elevates blood pressure and promotes atherosclerosis," Proceedings of the National Academy of Sciences of the United States of America, vol. 106, no. 19, pp. 7985-7990, 2009.

[150] J. W. Adams, D. S. Migita, M. K. Yu et al., "Prostaglandin F2 $\alpha$ stimulates hypertrophic growth of cultured neonatal rat ventricular myocytes," Journal of Biological Chemistry, vol. 271, no. 2, pp. 1179-1186, 1996.

[151] J. Lai, H. Jin, R. Yang et al., "Prostaglandin F $2 \alpha$ induces cardiac myocyte hypertrophy in vitro and cardiac growth in vivo," American Journal of Physiology, vol. 271, no. 6, pp. H2197-H2208, 1996.

[152] K. Pönicke, C. Giessler, M. Grapow et al., "FP-receptor mediated trophic effects of prostanoids in rat ventricular cardiomyocytes," British Journal of Pharmacology, vol. 129, no. 8, pp. 1723-1731, 2000.

[153] Y. Taba, T. Sasaguri, M. Miyagi et al., "Fluid shear stress induces lipocalin-type prostaglandin D2 synthase expression in vascular endothelial cells," Circulation Research, vol. 86, no. 9, pp. 967-973, 2000.

[154] R. L. Jones, M. A. Giembycz, and D. F. Woodward, "Prostanoid receptor antagonists: development strategies and 
therapeutic applications," British Journal of Pharmacology, vol. 158, no. 1, pp. 104-145, 2009.

[155] D. S. VanderEnde and J. D. Morrow, "Release of markedly increased quantities of prostaglandin D2 from the skin in vivo in humans after the application of cinnamic aldehyde," Journal of the American Academy of Dermatology, vol. 45, no. 1, pp. 62-67, 2001.

[156] L. Walch, C. Labat, J. P. Gascard, V. de Montpreville, C. Brink, and X. Norel, "Prostanoid receptors involved in the relaxation of human pulmonary vessels," British Journal of Pharmacology, vol. 126, no. 4, pp. 859-866, 1999.

[157] M. A. Wasserman, D. W. DuCharme, and R. L. Griffin, "Bronchopulmonary and cardiovascular effects of prostaglandin $\mathrm{D}_{2}$ in the dog," Prostaglandins, vol. 13, no. 2, pp. 255269, 1977.

[158] C. C. Hardy, C. Robinson, A. E. Tattersfield, and S. T. Holgate, "The bronchoconstrictor effect of inhaled prostaglandin D2 in normal and asthmatic men," New England Journal of Medicine, vol. 311, no. 4, pp. 209-213, 1984.

[159] S. L. Johnston, N. J. Freezer, W. Ritter, S. O’Toole, and P. H. Howarth, "Prostaglandin D2-induced bronchoconstriction is mediated only in part by the thromboxane prostanoid receptor," European Respiratory Journal, vol. 8, no. 3, pp. 411415, 1995.

[160] B. J. Whittle, S. Moncada, and J. R. Vane, "Comparison of the effects of prostacyclin (PGI2), prostaglandin E1 and $\mathrm{O}_{2}$ on platelet aggregation in different species," Prostaglandins, vol. 16, no. 3, pp. 373-388, 1978.

[161] B. Cooper, "Diminished platelet adenylate cyclase activation by prostaglandin D2 in acute thrombosis," Blood, vol. 54, no. 3, pp. 684-693, 1979.

[162] A. M. Siegl, "Receptors for PGI2 and PGD2 on human platelets," Methods in Enzymology, vol. 86, pp. 179-192, 1982.

[163] K. H. Thierauch, C. S. Stürzebecher, E. Schillinger et al., "Stable 9 beta- or 11 alpha-halogen-15-cyclohexyl-prostaglandins with high affinity to the PGD2-receptor," Advances in Prostaglandin, Thromboxane, and Leukotriene Research, vol. 19, pp. 655-658, 1989.

[164] M. Kiriyama, F. Ushikubi, T. Kobayashi, M. Hirata, Y. Sugimoto, and S. Narumiya, "Ligand binding specificities of the eight types and subtypes of the mouse prostanoid receptors expressed in Chinese hamster ovary cells," British Journal of Pharmacology, vol. 122, no. 2, pp. 217-224, 1997.

[165] Y. Cheng, S. C. Austin, B. Rocca et al., "Role of prostacyclin in the cardiovascular response to thromboxane $\mathrm{A}_{2}$," Science, vol. 296, no. 5567, pp. 539-541, 2002.

[166] T. Kobayashi, Y. Tahara, M. Matsumoto et al., "Roles of thromboxane $\mathrm{A}_{2}$ and prostacyclin in the development of atherosclerosis in apoE-deficient mice," Journal of Clinical Investigation, vol. 114, no. 6, pp. 784-794, 2004.

[167] H. Francois, K. Athirakul, L. Mao, H. Rockman, and T. M. Coffman, "Role for thromboxane receptors in angiotensinII-induced hypertension," Hypertension, vol. 43, no. 2, pp. 364-369, 2004.

[168] A. I. Ally and D. F. Horrobin, "Thromboxane $A_{2}$ in blood vessel walls and its physiological significance: relevance to thrombosis and hypertension," Prostaglandins and Medicine, vol. 4, no. 6, pp. 431-438, 1980.

[169] G. W. Dorn and A. DeJesus, "Human platelet aggregation and shape change are coupled to separate thromboxane $\mathrm{A}_{2}$ prostaglandin $\mathrm{H}_{2}$ receptors," American Journal of Physiology, vol. 260, no. 2, pp. H327-H334, 1991.
[170] R. F. Spurney, R. J. Bernstein, P. Ruiz, D. S. Pisetsky, and T. M. Coffman, "Physiologic role for enhanced renal thromboxane production in murine lupus nephritis," Prostaglandins, vol. 42, no. 1, pp. 15-28, 1991.

[171] S. D. Katugampola and A. P. Davenport, "Thromboxane receptor density is increased in human cardiovascular disease with evidence for inhibition at therapeutic concentrations by the AT1 receptor antagonist losartan," British Journal of Pharmacology, vol. 134, no. 7, pp. 1385-1392, 2001.

[172] W. Martin, "The combined role of atheroma, cholesterol, platelets, the endothelium and fibrin in heart attacks and strokes," Medical Hypotheses, vol. 15, no. 3, pp. 305-322, 1984.

[173] G. W. Dorn, N. Liel, J. L. Trask, D. E. Mais, M. E. Assey, and P. V. Halushka, "Increased platelet thromboxane $\mathrm{A}_{2} /$ prostaglandin $\mathrm{H}_{2}$ receptors in patients with acute myocardial infarction," Circulation, vol. 81, no. 1, pp. 212-218, 1990.

[174] J. M. Dogne, J. Hanson, and D. Pratico, "Thromboxane, prostacyclin andisoprostanes: therapeutic targets in atherogenesis," Trends in Pharmacological Sciences, vol. 26, no. 12, pp. 639-644, 2005.

[175] T. F. Lüscher, C. M. Boulanger, Y. Dohi, and Z. H. Yang, "Endothelium-derived contracting factors," Hypertension, vol. 19, no. 2, pp. 117-130, 1992.

[176] M. Félétou and P. M. Vanhoutte, "Endothelial dysfunction: a multifaceted disorder (The Wiggers Award Lecture)," American Journal of Physiology, vol. 291, no. 3, pp. H985-H1002, 2006.

[177] D. J. Fitzgerald, L. Roy, F. Catella, and G. A. Fitzderald, "Platelet activation in unstable coronary disease," New England Journal of Medicine, vol. 315, no. 16, pp. 983-989, 1986.

[178] K. Shinmura, K. Tamaki, T. Sato, H. Ishida, and R. Bolli, "Prostacyclin attenuates oxidative damage of myocytes by opening mitochondrial ATP-sensitive $\mathrm{K}^{+}$channels via the EP3 receptor," American Journal of Physiology, vol. 288, no. 5, pp. H2093-H2101, 2005.

[179] D. J. Fitzgerald, W. Rocki, R. Murray, G. Mayo, and G. A. FitzGerald, "Thromboxane $\mathrm{A}_{2}$ synthesis in pregnancyinduced hypertension," Lancet, vol. 335, no. 8692, pp. 751754, 1990.

[180] J. C. Keith Jr., B. Spitz, and F. A. van Assche, "Thromboxane synthetase inhibition as a new therapy for preeclampsia: animal and human studies minireview," Prostaglandins, vol. 45, no. 1, pp. 3-13, 1993.

[181] G. Shams, L. J. Wallace, D. D. Miller, and D. R. Feller, "Effects of thromboxane $\mathrm{A}_{2}$ on thoracic aorta of young and old rats: use of selective thromboxane receptor antagonists," Pharmacology, vol. 40, no. 1, pp. 27-32, 1990.

[182] P. M. Vanhoutte and E. H. Tang, "Endothelium-dependent contractions: when a good guy turns bad!," Journal of Physiology, vol. 586, no. 22, pp. 5295-5304, 2008.

[183] A. Hornych, F. Forette, J. Bariety, C. Krief, J. Aumont, and M. Paris, "The influence of age on renal prostaglandin synthesis in man," Prostaglandins Leukotrienes and Essential Fatty Acids, vol. 43, no. 3, pp. 191-195, 1991.

[184] J. Hou, K. Abe, and K. Yoshinaga, "The investigation about age-related changes in vasoactive substances of normal subjects and of patients with essential hypertension," Nippon Jinzo Gakkai Shi, vol. 34, no. 3, pp. 287-293, 1992.

[185] T. F. Lüscher, "Imbalance of endothelium-derived relaxing and contracting factors: a new concept in hypertension?" American Journal of Hypertension, vol. 3, no. 4, pp. 317-330, 1990. 
[186] B. W. Christman, C. D. McPherson, J. H. Newman et al., "An imbalance between the excretion of thromboxane and prostacyclin metabolites in pulmonary hypertension," New England Journal of Medicine, vol. 327, no. 2, pp. 70-75, 1992.

[187] C. R. Woodman, E. M. Price, and M. H. Laughlin, "Selected Contribution: aging impairs nitric oxide and prostacyclin mediation of endothelium-dependent dilation in soleus feed arteries," Journal of Applied Physiology, vol. 95, no. 5, pp. 2164-2170, 2003.

[188] M. H. Zou and V. Ullrich, "Peroxynitrite formed by simultaneous generation of nitric oxide and superoxide selectively inhibits bovine aortic prostacyclin synthase," FEBS Letters, vol. 382, no. 1-2, pp. 101-104, 1996.

[189] F. Santilli, G. Davì, S. Basili et al., "Thromboxane and prostacyclin biosynthesis in heart failure of ischemic origin: effects of disease severity and aspirin treatment," Journal of Thrombosis and Haemostasis, vol. 8, no. 5, pp. 914-922, 2010.

[190] M. M. Sellers and J. N. Stallone, "Sympathy for the devil: the role of thromboxane in the regulation of vascular tone and blood pressure," American Journal of Physiology, vol. 294, no. 5, pp. H1978-H1986, 2008.

[191] M. Félétou, P. M. Vanhoutte, and T. J. Verbeuren, "The thromboxane/endoperoxide receptor (TP): the common villain," Journal of Cardiovascular Pharmacology, vol. 55, no. 4, pp. 317-332, 2010.

[192] C. Y. Xiao, A. Hara, K. Yuhki et al., "Roles of prostaglandin $\mathrm{I}_{2}$ and thromboxane $\mathrm{A}_{2}$ in cardiac ischemia-reperfusion injury: a study using mice lacking their respective receptors," Circulation, vol. 104, no. 18, pp. 2210-2215, 2001.

[193] Y. Cheng, S. C. Austin, B. Rocca et al., "Role of prostacyclin in the cardiovascular response to thromboxane $\mathrm{A}_{2}$," Science, vol. 296, no. 5567, pp. 539-541, 2002.

[194] E. Arehart, J. Stitham, F. W. Asselbergs et al., "Acceleration of cardiovascular disease by a dysfunctional prostacyclin receptor mutation: potential implications for cyclooxygenase-2 inhibition," Circulation Research, vol. 102, no. 8, pp. 986-993, 2008.

[195] R. Ross, "The pathogenesis of atherosclerosis: a perspective for the 1990s," Nature, vol. 362, no. 6423, pp. 801-809, 1993.

[196] C. S. Baker, R. J. C. Hall, T. J. Evans et al., "Cyclooxygenase-2 is widely expressed in atherosclerotic lesions affecting native and transplanted human coronary arteries and colocalizes with inducible nitric oxide synthase and nitrotyrosine particularly in macrophages," Arteriosclerosis, Thrombosis, and Vascular Biology, vol. 19, no. 3, pp. 646-655, 1999.

[197] B. K. Hong, H. M. Kwon, B. K. Lee et al., "Coexpression of cyclooxygenase-2 and matrix metalloproteinases in human aortic atherosclerotic lesions," Yonsei Medical Journal, vol. 41, no. 1 , pp. 82-88, 2000.

[198] U. Schonbeck, G. K. Sukhova, P. Graber, S. Coulter, and P. Libby, "Augmented expression of cyclooxygenase-2 in human atherosclerotic lesions," American Journal of Pathology, vol. 155, no. 4, pp. 1281-1291, 1999.

[199] V. Stemme, J. Swedenborg, H. E. Claesson, and G. K. Hansson, "Expression of cyclo-oxygenase-2 in human atherosclerotic carotid arteries," European Journal of Vascular and Endovascular Surgery, vol. 20, no. 2, pp. 146-152, 2000.

[200] Y. F. Chen, S. Jowett, P. Barton et al., "Clinical and costeffectiveness of epoprostenol, iloprost, bosentan, sitaxentan and sildenafil for pulmonary arterial hypertension within their licensed indications: a systematic review and economic evaluation," Health Technology Assessment, vol. 13, no. 49, pp. 1-320, 2009.
[201] C. S. Peter and C. Peter, "Prostaglandins, prostacyclin, and thromboxane in cardiovascular diseases," Drug Development Research, vol. 7, no. 4, pp. 341-359, 1986.

[202] V. V. McLaughlin, S. P. Gaine, R. J. Barst et al., "Efficacy and safety of treprostinil: an epoprostenol analog for primary pulmonary hypertension," Journal of Cardiovascular Pharmacology, vol. 41, no. 2, pp. 293-299, 2003.

[203] N. Toda, "Beraprost sodium," Cardiovascular Drug Reviews, vol. 6, no. 3, pp. 222-238, 1988.

[204] T. Umetsu, T. Murata, Y. Tanaka, E. Osada, and S. Nishio, "Antithrombotic effect of TRK-100, a novel, stable $\mathrm{PGI}_{2}$ analogue," Japanese Journal of Pharmacology, vol. 43, no. 1, pp. 81-90, 1987.

[205] T. Umetsu, T. Murata, and S. Nishio, "Studies on the antiplatelet effect of the stable epoprostenol analogue beraprost sodium and its mechanism of action in rats," ArzneimittelForschung, vol. 39, no. 1, pp. 68-73, 1989.

[206] T. Murai, K. Muraoka, K. Saga et al., "Effect of beraprost sodium on peripheral circulation insufficiency in rats and rabbits," Arzneimittel-Forschung, vol. 39, no. 8, pp. 856-859, 1989.

[207] X. L. Ma, G. Johnson 3rd, and A. M. Lefer, "Low doses of superoxide dismutase and a stable prostacyclin analogue protect in myocardial ischemia and reperfusion," Journal of the American College of Cardiology, vol. 19, no. 1, pp. 197-204, 1992.

[208] P. S. Chan, P. Cervoni, P. A. Scully, M. A. Ronsberg, and R. C. Accomando, "Mechanism of action of a new prostaglandin antihypertensive, viprostol [CL 115 347; (dl)-15-deoxy-16hydroxy-16 $(\alpha / \beta)$-vinyl-prostaglandin $\mathrm{E}_{2}$ methyl ester]: (I) Vasodilation," Journal of Hypertension, vol. 4, no. 6, pp. 741747, 1986.

[209] P. S. Chan, P. Cervoni, R. C. Accomando, G. J. Quirk, and M. A. Ronsgerg, "Mechanism of action of a new prostaglandin antihypertensive, viprostol [CL 115 347; (dl)15-deoxy-16-hydroxy-16( $\alpha / \beta)$-vinyl prostaglandin $\mathrm{E}_{2}$ methyl ester]: (II) Effects on the adrenergic nervous system," Journal of Hypertension, vol. 4, no. 6, pp. 749-757, 1986.

[210] M. T. Olivari, T. B. Levine, and J. N. Cohn, "Evidence for a direct renal stimulating effect of prostaglandin $\mathrm{E}_{2}$ on renin release in patients with congestive heart failure," Circulation, vol. 74, no. 6, pp. 1203-1207, 1986.

[211] J. A. Haas, T. G. Hammond, J. P. Granger, E. H. Blaine, and F. G. Knox, "Mechanism of natriuresis during intrarenal infusion of prostaglandins," The American Journal of Physiology, vol. 247, no. 3, pp. F475-479, 1984.

[212] S. Katayama, A. A. Attallah, R. A. Stahl, D. L. Bloch, and J. B. Lee, "Mechanism of furosemide-induced natriuresis by direct stimulation of renal prostaglandin $\mathrm{E}_{2}$," The American Journal of Physiology, vol. 247, no. 4, pp. F555-561, 1984.

[213] J. B. Stokes, "Integrated actions of renal medullary prostaglandins in the control of water excretion," The American Journal of Physiology, vol. 240, no. 6, pp. F471-F480, 1981.

[214] P. M. Olley, F. Coceani, and E. Bodach, "E-type prostaglandins: a new emergency therapy for certain cyanotic congenital heart malformations," Circulation, vol. 53, no. 4, pp. 728-731, 1976.

[215] M. A. Heymann, "Pharmacologic use of prostaglandin E1 in infants with congenital heart disease," American Heart Journal, vol. 101, no. 6, pp. 837-843, 1981.

[216] E. D. Silove, D. G. V. Roberts, and J. V. de Giovanni, "Evaluation of oral and low dose intravenous prostaglandin $\mathrm{E}_{2}$ in management of ductus dependent congenital heart 
disease," Archives of Disease in Childhood, vol. 60, no. 11, pp. 1025-1030, 1985.

[217] E. D. Silove, J. Y. Coe, M. F. Shiu et al., "Oral prostaglandin $\mathrm{E}_{2}$ in ductus-dependent pulmonary circulation," Circulation, vol. 63, no. 3, pp. 682-688, 1981.

[218] G. I. Fiddler and P. Lumley, "Preliminary clinical studies with thromboxane synthase inhibitors and thromboxane receptor blockers. A review," Circulation, vol. 81, supplement I, no. 1, pp. I -69-I -78, 1990.

[219] E. W. Jones, S. R. Cockbill, A. J. Cowley et al., "Effects of dazoxiben and low-dose aspirin on platelet behaviour in man," British Journal of Clinical Pharmacology, vol. 15, supplement 1, pp. 39S-44S, 1983.

[220] M. A. Villalobos, J. P. de La Cruz, R. Escalante, M. M. Arrebola, A. Guerrero, and F. Sánchez de la Cuesta, "Effects of camonagrel, a selective inhibitor of platelet thromboxane synthase, on the platelet-subendothelium interaction," Pharmacology, vol. 69, no. 1, pp. 44-50, 2003.

[221] S. J. Coker and J. R. Parratt, "The effects of dazoxihen on arrhythmias and ventricular fibrillation induced by coronary, artery occlusion and reperfusion," British Journal of Clinical Pharmacology, vol. 15, supplement 1, pp. 87S-95S, 1983.

[222] S. J. Coker, "Further evidence that thromboxane exacerbates arrhythmias: effects of UK38485 during coronary artery occlusion and reperfusion in anaesthetized greyhounds," Journal of Molecular and Cellular Cardiology, vol. 16, no. 7, pp. 633-641, 1984.

[223] G. G. Neri Serneri, S. Coccheri, E. Marubini, and F. Violi, "Picotamide, a combined inhibitor of thromboxane $\mathrm{A}_{2}$ synthase and receptor, reduces 2 -year mortality in diabetics with peripheral arterial disease: the DAVID study," European Heart Journal, vol. 25, no. 20, pp. 1845-1852, 2004.

[224] A. Vetrano, M. Milani, and G. Corsini, "Effects of aspirin or picotamide, an antithromboxane agent, in combination with low-intensity oral anticoagulation in patients with acute myocardial infarction: a controlled randomized pilot trial," Giornale Italiano di Cardiologia Journal, vol. 29, no. 5, pp. 524-528, 1999.

[225] M. Cocozza, T. Picano, U. Oliviero, N. Russo, V. Coto, and M. Milani, "Effects of picotamide, an antithromboxane agent, on carotid atherosclerotic evolution: a two-year, double-blind, placebo-controlled study in diabetic patients," Stroke, vol. 26, no. 4, pp. 597-601, 1995.

[226] M. G. Hennerici, M. L. Bots, I. Ford, S. Laurent, and P. J. Touboul, "Rationale, design and population baseline characteristics of the PERFORM Vascular Project: an ancillary study of the Prevention of cerebrovascular and cardiovascular events of ischemic origin with terutroban in patients with a history of ischemic stroke or transient ischemic attack (PERFORM) trial," Cardiovascular Drugs and Therapy, vol. 24, no. 2, pp. 175-180, 2010.

[227] S. Simonet, J. J. Descombes, M. O. Vallez et al., "S 18886, a new thromboxane (TP)-receptor antagonist is the active isomer of S 18204 in all species, except in the guinea-pig," Advances in Experimental Medicine and Biology, vol. 433, pp. 173-176, 1997.

[228] A. G. Johnson, T. V. Nguyen, and R. O. Day, "Do nonsteroidal anti-inflammatory drugs affect blood pressure? A metaanalysis," Annals of Internal Medicine, vol. 121, no. 4, pp. 289300, 1994.

[229] S. K. Swan, D. W. Rudy, K. C. Lasseter et al., "Effect of cyclooxygenase-2 inhibition on renal function in elderly persons receiving a low-salt diet: a randomized, controlled trial," Annals of Internal Medicine, vol. 133, no. 1, pp. 1-9, 2000.

[230] C. J. Hawkey, G. M. Hawkey, S. Everitt, M. M. Skelly, W. A. Stack, and D. Gray, "Increased risk of myocardial infarction as first manifestation of ischaemic heart disease and nonselective nonsteroidal anti-inflammatory drugs," British Journal of Clinical Pharmacology, vol. 61, no. 6, pp. 730-737, 2006.

[231] S. Husain, N. P. Andrews, D. Mulcahy, J. A. Panza, and A. A. Quyyumi, "Aspirin improves endothelial dysfunction in atherosclerosis," Circulation, vol. 97, no. 8, pp. 716-720, 1998.

[232] V. Fuster, M. L. Dyken, P. S. Vokonas, and C. Hennekens, "Aspirin as a therapeutic agent in cardiovascular disease. Special Writing Group," Circulation, vol. 87, no. 2, pp. 659675, 1993.

[233] Antiplatelet Trials Collaboration, "Collaborative overview of randomized trials of antiplatelet therapy, I: prevention of death, myocardial infarction, and stroke by prolonged antiplatelet therapy in various categories of patients," British Medical Journal, vol. 308, no. 6921, pp. 81-106, 1994.

[234] G. J. Roth and P. W. Majerus, "The mechanism of the effect of aspirin on human platelets. I. Acetylation of a particulate fraction protein, Annual Review of Pharmacology and Toxicology," The Journal of Clinical Investigation, vol. 56, no. 3, pp. 624-632, 1975.

[235] P. J. Loll, D. Picot, and R. M. Garavito, "The structural basis of aspirin activity inferred from the crystal structure of inactivated prostaglandin $\mathrm{H}_{2}$ synthase," Nature Structural \& Molecular Biology, vol. 2, no. 8, pp. 637-643, 1995.

[236] J. R. Vane, Y. S. Bakhle, and R. M. Botting, "Cyclooxygenases 1 and 2," Annual Review of Pharmacology and Toxicology, vol. 38, pp. 97-120, 1998.

[237] P. Pignatelli, S. di Santo, F. Barillá, C. Gaudio, and F. Violi, "Multiple anti-atherosclerotic treatments impair aspirin compliance: effects on aspirin resistance," Journal of Thrombosis and Haemostasis, vol. 6, no. 10, pp. 1832-1834, 2008.

[238] J. Dawson, T. Quinn, M. Rafferty et al., "Aspirin resistance and compliance with therapy," Cardiovascular Therapeutics, vol. 29, no. 5, pp. 301-307, 2011.

[239] G. Di Minno, "Aspirin resistance and platelet turnover: a 25-year old issue," Nutrition, Metabolism and Cardiovascular Diseases, vol. 21, no. 8, pp. 542-545, 2011.

[240] A. Szczeklik, J. Musiał, A. Undas, and M. Sanak, "Aspirin resistance," Journal of Thrombosis and Haemostasis, vol. 3, no. 8, pp. 1655-1662, 2005.

[241] T. Goodman, A. Ferro, and P. Sharma, "Pharmacogenetics of aspirin resistance: a comprehensive systematic review," British Journal of Clinical Pharmacology, vol. 66, no. 2, pp. 222-331, 2008.

[242] G. Krasopoulos, S. J. Brister, W. S. Beattie, and M. R. Buchanan, "Aspirin "resistance" and risk of cardiovascular morbidity: systematic review and meta-analysis," British Medical Journal, vol. 336, no. 7637, pp. 195-198, 2008.

[243] J. D. Snoep, M. M. Hovens, J. C. Eikenboom, J. G. van der Bom, and M. V. Huisman, "Association of laboratory-defined aspirin resistance with a higher risk of recurrent cardiovascular events: a systematic review and meta-analysis," Archives of Internal Medicine, vol. 167, no. 15, pp. 1593-1599, 2007.

[244] J. W. Eikelboom, J. Hirsh, J. I. Weitz, M. Johnston, Q. Yi, and S. Yusuf, "Aspirin-resistant thromboxane biosynthesis and the risk of myocardial infarction, stroke, or cardiovascular 
death in patients at high risk for cardiovascular events," Circulation, vol. 105, no. 14, pp. 1650-1655, 2002.

[245] H. H. Tai, H. Cho, M. Tong, and Y. Ding, "NAD'-linked 15hydroxyprostaglandin dehydrogenase: structure and biological function," Current Pharmaceutical Design, vol. 12, no. 8, pp. 955-962, 2006.

[246] M. E. Rudock, Y. Liu, J. T. Ziegler et al., "Association of polymorphisms in cyclooxygenase (COX)-2 with coronary and carotid calcium in the Diabetes Heart Study," Atherosclerosis, vol. 203, no. 2, pp. 459-465, 2009.

[247] J. Helmersson, J. Ärnlöv, T. Axelsson, and S. Basu, "A polymorphism in the cyclooxygenase 1 gene is associated with decreased inflammatory prostaglandin F $2 \alpha$ formation and lower risk of cardiovascular disease," Prostaglandins Leukotrienes and Essential Fatty Acids, vol. 80, no. 1, pp. 51-56, 2009.

[248] T. Nakayama, "Prostacyclin synthase gene: genetic polymorphisms and prevention of some cardiovascular diseases," Current Medicinal Chemistry: Cardiovascular and Hematological Agents, vol. 3, no. 2, pp. 157-164, 2005.

[249] J. Stitham, A. Stojanovic, and J. Hwa, "Impaired receptor binding and activation associated with a human prostacyclin receptor polymorphism," Journal of Biological Chemistry, vol. 277, no. 18, pp. 15439-15444, 2002.

[250] R. N. Lemaitre, K. Rice, K. Marciante et al., "Variation in eicosanoid genes, non-fatal myocardial infarction and ischemic stroke," Atherosclerosis, vol. 204, no. 2, pp. e58-e63, 2009.

[251] M. Hamberg and B. Samuelsson, "On the metabolism of prostaglandins E 1 and E 2 in man," Journal of Biological Chemistry, vol. 246, no. 22, pp. 6713-6721, 1971.

[252] R. Nomura, R. Lu, M. L. Pucci, and V. L. Schuster, "The two-step model of prostaglandin signal termination: in vitro reconstitution with the prostaglandin transporter and prostaglandin 15 dehydrogenase," Molecular Pharmacology, vol. 65, no. 4, pp. 973-978, 2004.

[253] H. Y. Chang, J. Locker, R. Lu, and V. L. Schuster, "Failure of postnatal ductus arteriosus closure in prostaglandin transporter-deficient mice," Circulation, vol. 121, no. 4, pp. 529536, 2010.

[254] Y. Chi, J. Min, J. F. Jasmin, M. P. Lisanti, Y. T. Chang, and V. L. Schuster, "Development of a high affinity inhibitor of the prostaglandin transporter PGT," Journal of Pharmacology and Experimental Therapeutics, vol. 339, no. 2, pp. 529-536, 2011. 


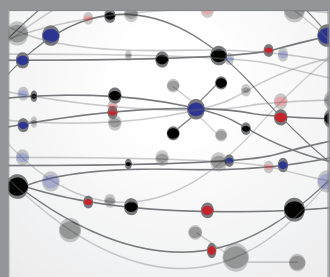

The Scientific World Journal
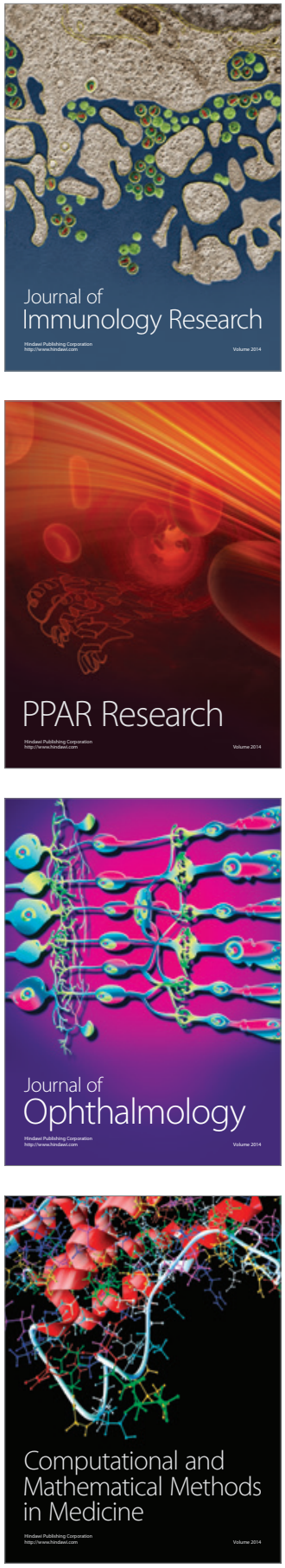

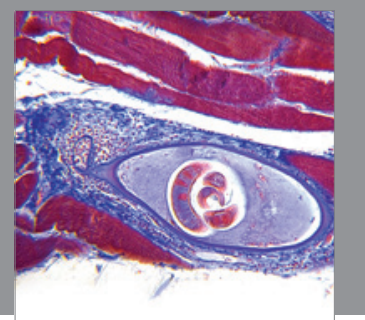

Gastroenterology

Research and Practice
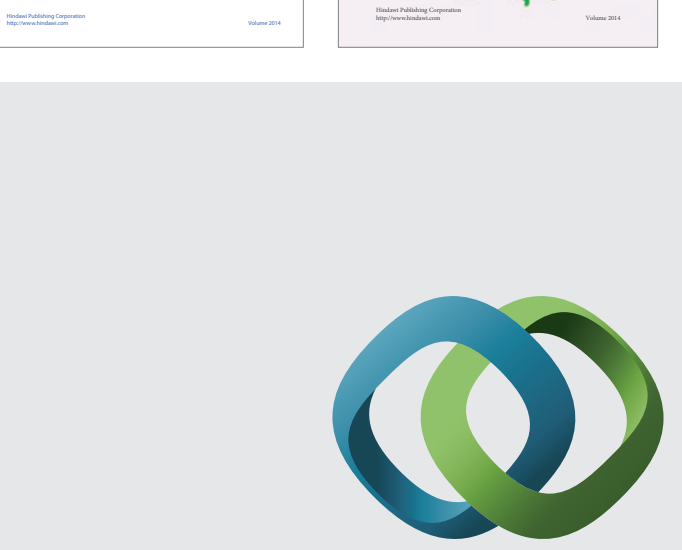

\section{Hindawi}

Submit your manuscripts at

http://www.hindawi.com
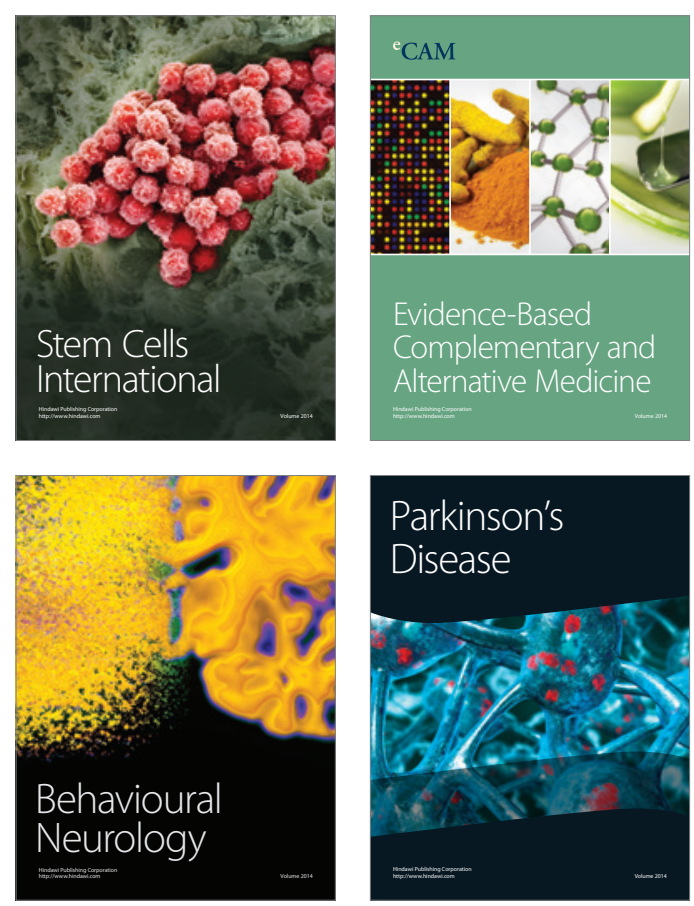

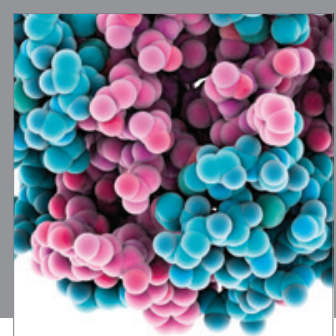

Journal of
Diabetes Research

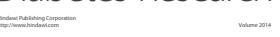

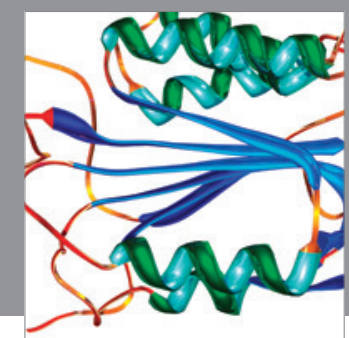

Disease Markers
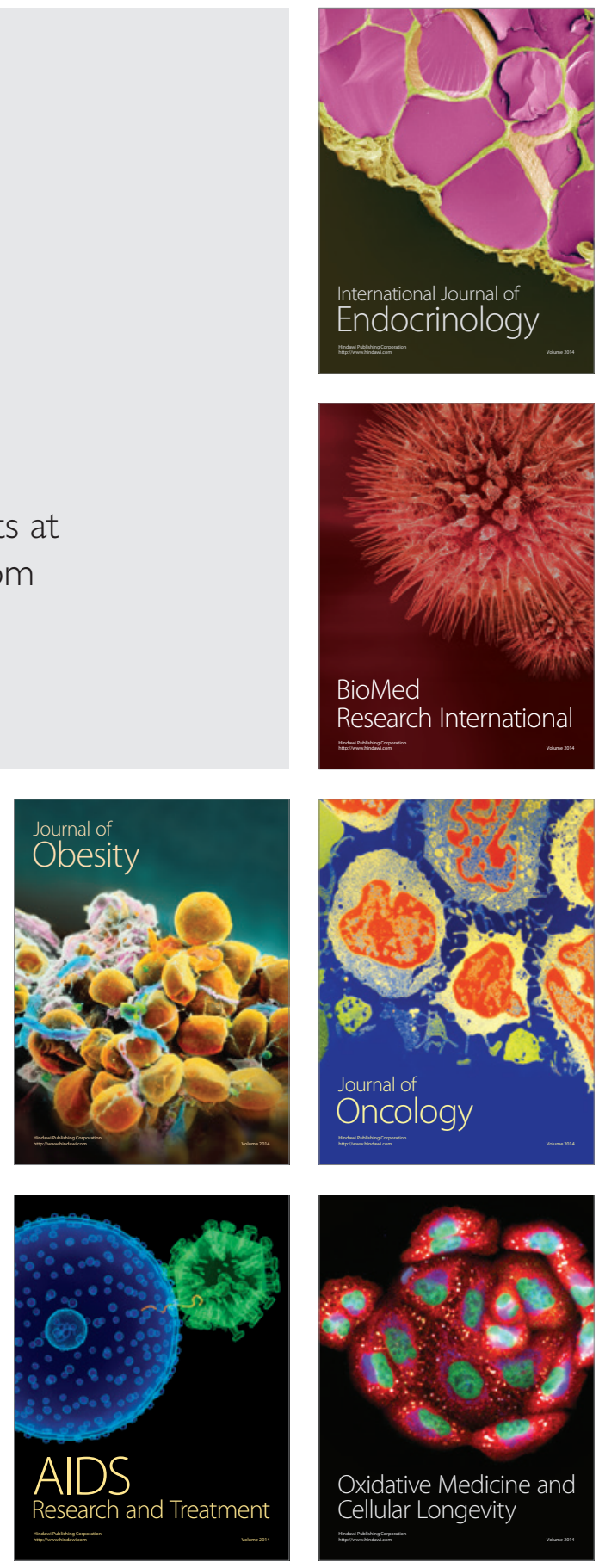